\title{
KENTUCKY PIONEER ENERGY LLC INTEGRATED GASIFICATION COMBINED CYCLE PROJECT 2 MW FUEL CELL DEMONSTRATION
}

Cooperative Agreement DE-FC21-95MC31262

Subcontract KPE 2000-01

FINAL REPORT

February 15, 2006

Submitted to:

Global Energy Inc.

312 Walnut St. Suite 2650

Cincinnati, OH 45202

$$
\text { and }
$$

U.S. Department of Energy

National Energy Technology Laboratory

626 Cochrans Mill Road

Pittsburgh, PA 15236-0940

Submitted by:

FuelCell Energy, Inc.

3 Great Pasture Road

Danbury, CT 06813-1305 


\section{DISCLAIMER}

This report was prepared as an account of work sponsored by an agency of the United States Government. Neither the United States Government nor any agency thereof, nor any of their employees, makes any warranty, express or implied, or assumes any legal liability or responsibility for the accuracy, completeness, or usefulness of any information, apparatus, product, or process disclosed, or represents that its use would not infringe privately owned rights. Reference herein to any specific commercial product, process, or service by trade name, trademark, manufacturer, or otherwise does not necessarily constitute or imply its endorsement, recommendation, or favoring by the United States Government or any agency thereof. The views and opinions of authors expressed herein do not necessarily state or reflect those of the United States Government or any agency thereof. 
FuelCell Energy, Inc.

Final Report
Kentucky Pioneer Energy LLC, IGCC Project 2 MW Fuel Cell Demonstration Cooperative Agreement DE-FC21-95MC31262

Subcontract KPE 2000-01

\section{TABLE OF CONTENTS}

Page No.

List of Acronyms and Abbreviations $\quad$ iv

$\begin{array}{ll}\text { Executive Summary } & 1\end{array}$

1.0 Background 2

$2.0 \quad$ Project Objective 4

3.0 Integrated Gasification Fuel Cell $\quad 4$

$\begin{array}{lll}4.0 & \text { Project Description } & 6\end{array}$

5.0 Fuel Cell Power Plant Description 9

$\begin{array}{lll}\text { 6.0 } & \text { Cost and Schedule } & 13\end{array}$

$\begin{array}{lll}7.0 & \text { Commercial Applications } & 15\end{array}$

$\begin{array}{lll}8.0 & \text { Future Developments } & 25\end{array}$

9.0 Market Potential 33

$\begin{array}{lll}10.0 & \text { Conclusions } & 36\end{array}$

$\begin{array}{ll}\text { Bibliography } & 39\end{array}$

Appendix A: Fuel Cell Power Plant Operating on Syngas - Process Flow Diagram

Appendix B-1: Calculated Stream Data for Syngas Operation

Appendix B-2: Calculated Stream Data Natural Gas Operation

Appendix C: Syngas Treatment System - Process Flow Diagram and Equipment Layout

Appendix D: Plot Plan for Entire Fuel Cell Power Plant 
FuelCell Energy, Inc.

Final Report
Kentucky Pioneer Energy LLC, IGCC Project 2 MW Fuel Cell Demonstration Cooperative Agreement DE-FC21-95MC31262

Subcontract KPE 2000-01

\section{LIST OF FIGURES}

Figure No.

Page No.

1-1 U.S. Electric Generation by Fuel Type 3

1-2 $20 \mathrm{~kW}$ Carbonate Fuel Cell Test at the LGTI Gasification Facility 4 Completed in 1992

3-1 Simplified Process Flow Diagram for Integrated Gasification Fuel Cell (IGFC)

3-2 Environmental Impact Comparison of IGFC and Other Technologies

4-1 Wabash River Energy Ltd. Coal Gasification Site $\quad 6$

4-2 Simplified Process Flow Diagram of the Wabash River IGCC with 8 Fuel Cell Operating on a Slip Stream

5-1 Carbonate Fuel Cell Power Plant Simplified Process Schematic 9

5-2 Conditioning of 1 MW Modules at FuelCell Energy 10

5-3 2 MW Carbonate Fuel Cell Power Plant with Syngas Processing 11 Skids Installed at Wabash

7-1 Fuel Cell Power Plant Products Offered for Commercial Applications 16 by FuelCell Energy

8-1 DFC/T ${ }^{\circledR}$ Ultra High Efficiency System Concept $\quad 26$

8-2 Process Flow Diagram Of The Long-Term Multi-MW DFC/T 28 Hybrid System

8-3 40 MW Plant Layout/Plot Plan 30

8-4 Schematic of Bulk Hydrogen Separation form Coal Gasifier Streams 32

10-1 2 MW Fuel Cell Power Plant With Syngas Processing Installed at the 37 Wabash River Energy Ltd Gasification Plant in Terre Haute, Indiana

4

8

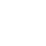

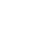

.

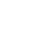

10

1


FuelCell Energy, Inc.

Final Report
Kentucky Pioneer Energy LLC, IGCC Project 2 MW Fuel Cell Demonstration Cooperative Agreement DE-FC21-95MC31262

Subcontract KPE 2000-01

\section{LIST OF TABLES}

Table No.

4-1 Typical Product Syngas Analysis at the Wabash River Gasification Site

5-1 Summary of Major Equipment for the Fuel Cell Power Plant

5-2 Plant Design Performance on Syngas

13

5-3 Plant Design Performance on Natural Gas

6-1 Plant Cost Breakdown

14

6-2 Estimated Operation and Maintenance Cost

6-3 Comparison of Planned and Actual Completion of Key Milestones

16

8-1 Multi-MW DFC/T Power Plant (Baseline Configuration) Performance Projections

8-2 40 MW DFC/T Hybrid Power Plant Performance (Estimate)

9-1 Summary of Product Applications

9-2 Expansion of Markets For Coal Fired Power Plants 


\section{LIST OF ACRONYMS}

$\begin{array}{ll}\text { ABI } & \text { Applied Business Intelligence } \\ \text { APU } & \text { Auxiliary Power Unit } \\ \text { BGL } & \text { British Gas Lurgi } \\ \text { BOP } & \text { Balance of Plant } \\ \text { CARB } & \text { California Air Resources Board } \\ \text { CCTDP } & \text { Clean Coal Technology Demonstration Program } \\ \text { CHP } & \text { Combined Heat and Power } \\ \text { COE } & \text { Cost of Energy } \\ \text { COS } & \text { Carbonyl Sulfide } \\ \text { DFC } & \text { Direct Fuel Cell } \\ \text { DFC/T } & \text { Direct Fuel Cell/Turbine } \\ \text { DOE } & \text { Department of Energy } \\ \text { EIA } & \text { Energy Information Administration } \\ \text { EPRI } & \text { Electric Power Research Institute } \\ \text { FCCG } & \text { Fuel Cell Commercialization Group } \\ \text { FCE } & \text { FuelCell Energy, Inc. } \\ \text { HHV } & \text { Higher Heating Value } \\ \text { HTR } & \text { High Temperature Recuperator } \\ \text { HRSG } & \text { Heat Recovery Steam Generator } \\ \text { HRU } & \text { Heat Recovery Unit } \\ \text { IGBT } & \text { Insulated Gate Bipolar Transistor } \\ \text { IGCC } & \text { Integrated Gasification Combined Cycle } \\ \text { IGFC } & \text { Integrated Gasification Fuel Cell } \\ \text { IGHFC } & \text { Integrated Gasification Hybrid Fuel Cell } \\ \text { IOU } & \text { Investor Owned Utility } \\ \text { IPP } & \text { Independent Power Producer } \\ \text { KPE } & \text { Kentucky Pioneer Energy } \\ \text { LGTI } & \text { Louisiana Gasification Technology Inc. } \\ \text { LTR } & \text { Low Temperature Recuperator } \\ \text { MDEA } & \text { Methyldiethanolamine } \\ \text { NETL } & \text { National Energy Technology Laboratory } \\ \text { PAFC } & \text { Phosphoric Acid Fuel Cell } \\ \text { PCS } & \text { Power Conditioning Unit } \\ \text { PEM } & \text { Polymer Electrolyte Membrane } \\ \text { PFD } & \text { Process Flow Diagram } \\ \text { REC } & \text { Rural Electric Cooperatives } \\ \text { RPS } & \text { Renewable Portfolio Standard } \\ \text { SECA } & \text { Solid State Energy Conversion Alliance } \\ \text { SOFC } & \text { Solid Oxide Fuel Cell } \\ \text { VPS } & \text { Versa Power Systems } \\ \text { WREL } & \text { Wabash River Energy Ltd. } \\ & \end{array}$




\section{EXECUTIVE SUMMARY}

With about $50 \%$ of power generation in the United States derived from coal and projections indicating that coal will continue to be the primary fuel for power generation in the next two decades, the Department of Energy (DOE) Clean Coal Technology Demonstration Program (CCTDP) has been conducted since 1985 to develop innovative, environmentally friendly processes for the world energy market place.

The 2 MW Fuel Cell Demonstration was part of the Kentucky Pioneer Energy (KPE) Integrated Gasification Combined Cycle (IGCC) project selected by DOE under Round Five of the Clean Coal Technology Demonstration Program. The participant in the CCTDP V Project was Kentucky Pioneer Energy for the IGCC plant. FuelCell Energy, Inc. (FCE), under subcontract to $\mathrm{KPE}$, was responsible for the design, construction and operation of the $2 \mathrm{MW}$ fuel cell power plant. Duke Fluor Daniel provided engineering design and procurement support for the balanceof-plant skids. Colt Engineering Corporation provided engineering design, fabrication and procurement of the syngas processing skids. Jacobs Applied Technology provided the fabrication of the fuel cell module vessels. Wabash River Energy Ltd (WREL) provided the test site.

The 2 MW fuel cell power plant utilizes FuelCell Energy’s Direct Fuel Cell (DFC) technology, which is based on the internally reforming carbonate fuel cell. This plant is capable of operating on coal-derived syngas as well as natural gas. Prior testing (1992) of a subscale $20 \mathrm{~kW}$ carbonate fuel cell stack at the Louisiana Gasification Technology Inc. (LGTI) site using the Dow/Destec gasification plant indicated that operation on coal derived gas provided normal performance and stable operation. Duke Fluor Daniel and FuelCell Energy developed a commercial plant design for the $2 \mathrm{MW}$ fuel cell. The plant was designed to be modular, factory assembled and truck shippable to the site. Five balance-of-plant skids incorporating fuel processing, anode gas oxidation, heat recovery, water treatment/instrument air, and power conditioning/controls were built and shipped to the site. The two fuel cell modules, each rated at $1 \mathrm{MW}$ on natural gas, were fabricated by FuelCell Energy in its Torrington, CT manufacturing facility. The fuel cell modules were conditioned and tested at FuelCell Energy in Danbury and shipped to the site. Installation of the power plant and connection to all required utilities and syngas was completed. Pre-operation checkout of the entire power plant was conducted and the plant was ready to operate in July 2004. However, fuel gas (natural gas or syngas) was not available at the WREL site due to technical difficulties with the gasifier and other issues. The fuel cell power plant was therefore not operated, and subsequently removed by October of 2005. The WREL fuel cell site was restored to the satisfaction of WREL.

FuelCell Energy continues to market carbonate fuel cells for natural gas and digester gas applications. A fuel cell/turbine hybrid is being developed and tested that provides higher efficiency with potential to reach the DOE goal of $60 \% \mathrm{HHV}$ on coal gas. A system study was conducted for a $40 \mathrm{MW}$ direct fuel cell/turbine hybrid (DFC/T) with potential for future coal gas applications. In addition, FCE is developing Solid Oxide Fuel Cell (SOFC) power plants with Versa Power Systems (VPS) as part of the Solid State Energy Conversion Alliance (SECA) 
FuelCell Energy, Inc.

Final Report
Kentucky Pioneer Energy LLC, IGCC Project 2 MW Fuel Cell Demonstration Cooperative Agreement DE-FC21-95MC31262

Subcontract KPE 2000-01

program and has an on-going program for co-production of hydrogen. Future development in these technologies can lead to future coal gas fuel cell applications. 
FuelCell Energy, Inc.

Final Report
Kentucky Pioneer Energy LLC, IGCC Project

2 MW Fuel Cell Demonstration

Cooperative Agreement DE-FC21-95MC31262

Subcontract KPE 2000-01

\subsection{BACKGROUND}

Power generation in the United States relies heavily on coal with just over $50 \%$ of the power generated using coal in 2004 as shown in Figure 1. As total U.S. coal consumption increases from 1050 to 1444 million short tons a year between 2001 and 2025, the average annual increase is projected to be 1.3 percent. About 92 percent of the coal consumed in the U.S. is used for power generation. In the next two decades, coal is expected to remain the primary fuel for power generation, although its share of total generation is expected to decline from $50 \%$ to $47 \%$ by 2025 as natural gas increases its share. It is projected that 74 gigawatts of new coal-fired generating capacity will be constructed between 2001 and $2025^{2}$.
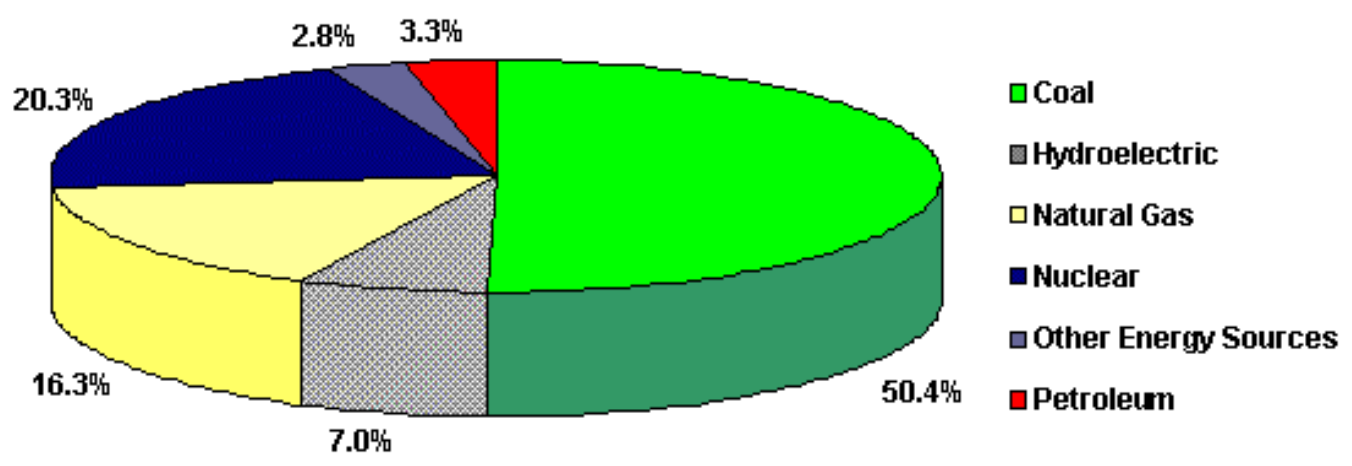

Figure 1-1. 2004 U.S. Electric Generation by Fuel Type

Source: U.S. DOE/EIA “Electric Power Monthly” (2004 Data for U.S. Electric Utilities)

As concern about the environment generates interest in ultra-clean energy, plants are needed to respond to the challenge. The Clean Coal Technology Demonstration Program, sponsored by the U.S. Department of Energy and administered by the National Energy Technology Laboratory (NETL), has been conducted since 1985 to develop innovative, environmentally friendly coal utilization processes for the world energy market place.

The CCTDP, which is co-funded by industry and government, involves a series of commercial scale demonstration projects that provide data for design, construction, operation and technical /economic evaluation of full-scale applications. The goal of the CCTDP is to enhance the utilization of coal as a major energy source.

Experimental testing of a $20 \mathrm{~kW}$ subscale fuel cell stack was conducted ${ }^{10}$ at Louisiana Gasification Technology Inc. (LGTI) in 1993-4 by Destec as shown in Figure 1-2. This was the world's first test of a carbonate fuel cell on coal-derived gas. Gas from the entrained flow Destec gasifier was further cleaned-up after bulk gas cleanup by the fuel cell test facility and supplied to the fuel cell. The fuel cell operated on syngas from the gasifier and interchangeably with natural gas providing normal performance and stable operation. After completion of the test, the fuel cell was disassembled for post-test inspection. Analysis of the components indicated no evidence of degradation and no detectable accumulation of coal gas borne 
FuelCell Energy, Inc.

Final Report
Kentucky Pioneer Energy LLC, IGCC Project

2 MW Fuel Cell Demonstration

Cooperative Agreement DE-FC21-95MC31262

Subcontract KPE 2000-01

contaminants in the fuel cell electrolyte or in the hardware. These results paved the way for a larger scale demonstration test.

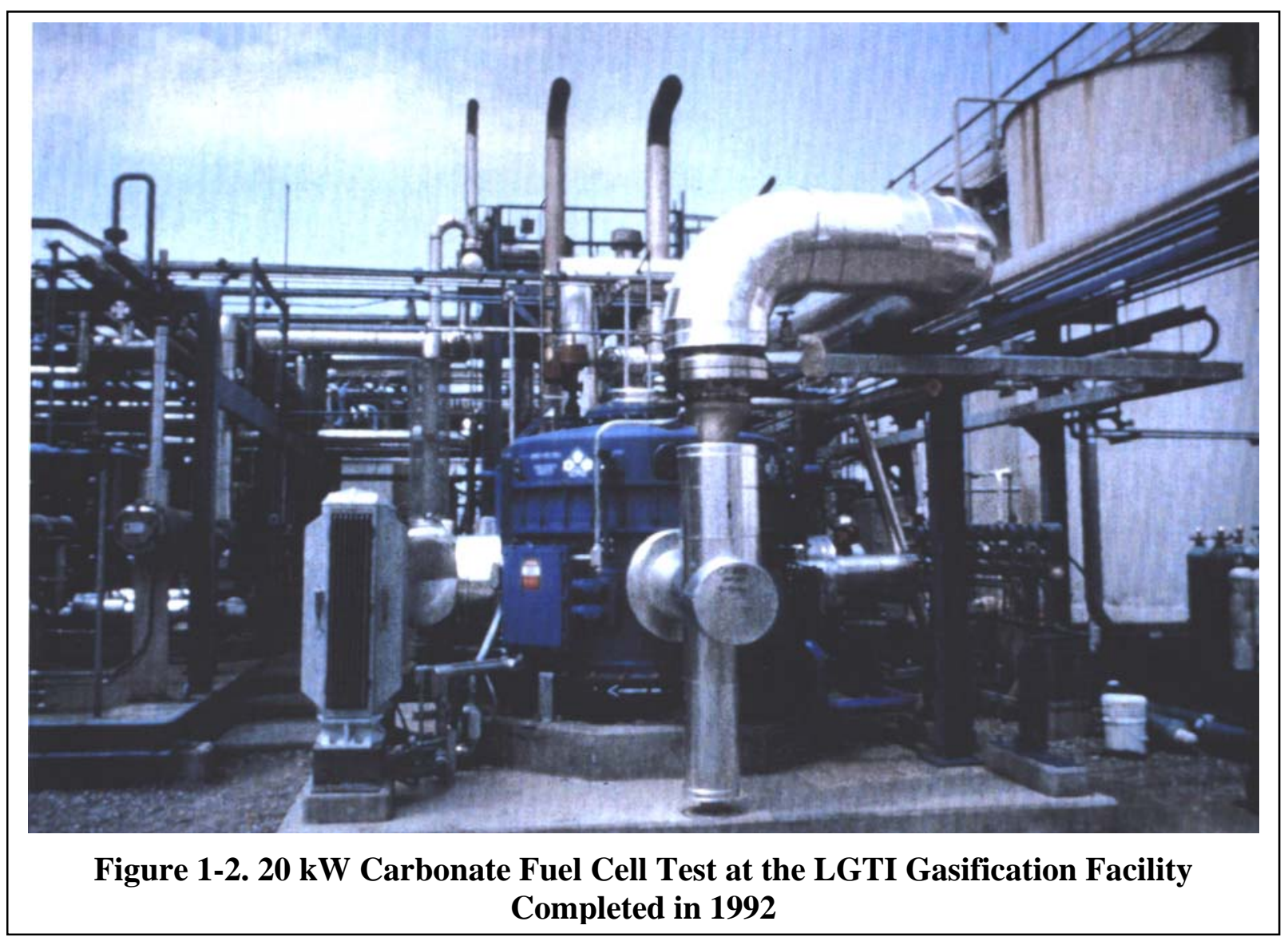

\subsection{PROJECT OBJECTIVE}

The project objective was to demonstrate the significant improvement in efficiency and environmental performance of carbonate fuel cell technology in coal based power generation systems. In addition, the scale-up, operation and reliability of a carbonate fuel cell operating on sygnas were to be demonstrated. To achieve this objective, a $2 \mathrm{MW}$ carbonate fuel cell power plant was to be designed, constructed, and operated at the Wabash River Energy Integrated Gasification Combined Cycle (IGCC) project site in Terre Haute, Indiana as part of the Kentucky Pioneer IGCC Demonstration Project.

\subsection{INTEGRATED GASIFICATION FUEL CELL}

Fuel cell systems operating on coal have been studied extensively in past years. Gasification is used to convert the solid fuel to a gas, which is processed to remove sulfur compounds, tars, particulates, and trace contaminants. The cleaned fuel gas is converted to electricity in a high temperature fuel cell. Waste heat from the carbonate fuel cell is used to generate steam required for the gasification process and to generate additional power in a bottoming cycle. 
FuelCell Energy, Inc.

Final Report
Kentucky Pioneer Energy LLC, IGCC Project 2 MW Fuel Cell Demonstration Cooperative Agreement DE-FC21-95MC31262

Subcontract KPE 2000-01

At a $200 \mathrm{MW}$ scale, past studies ${ }^{5,6,7}$ indicated that using conventional gasification and clean-up technologies, a heat rate of $7186 \mathrm{Btu} / \mathrm{kWh}$ (47.5\% HHV efficiency) can be achieved with the Integrated Gasification Fuel Cell (IGFC) power plant. This plant would require 2139 tons/day coal and generate a net output of $250 \mathrm{MW}$. Later studies ${ }^{8,9,12}$ indicated that higher efficiencies, $51.7 \%-53.5 \%$, could be achieved with higher methane producing gasifiers and by using hot gas clean up. Figure 3-1 shows a simplified process flow diagram for the IGFC system.

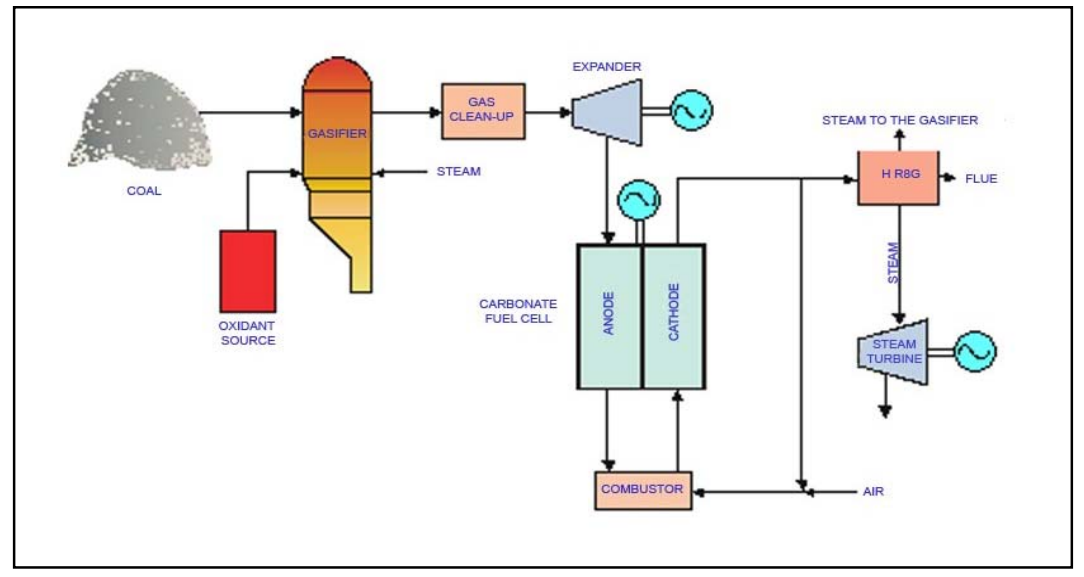

Figure 3- 1. Simplified Process Flow Diagram for Integrated Gasification Fuel Cell (IGFC)

Emissions from this plant would be below any current or anticipated future standards. Figure 3-2 compares the combined $\mathrm{SO}_{\mathrm{x}}, \mathrm{NO}_{\mathrm{x}}$, and solid waste emissions of existing commercial technologies, IGCC and IGFC. IGFC technology achieves the lowest levels of pollutant emissions in addition to lower $\mathrm{CO}_{2}$ emissions and make-up water requirements. The $\mathrm{CO}_{2}$ emission is $1.54 \mathrm{lb} / \mathrm{kWh}$ and the make-up water requirement is $6.8 \mathrm{GPM} / \mathrm{MWh}$.

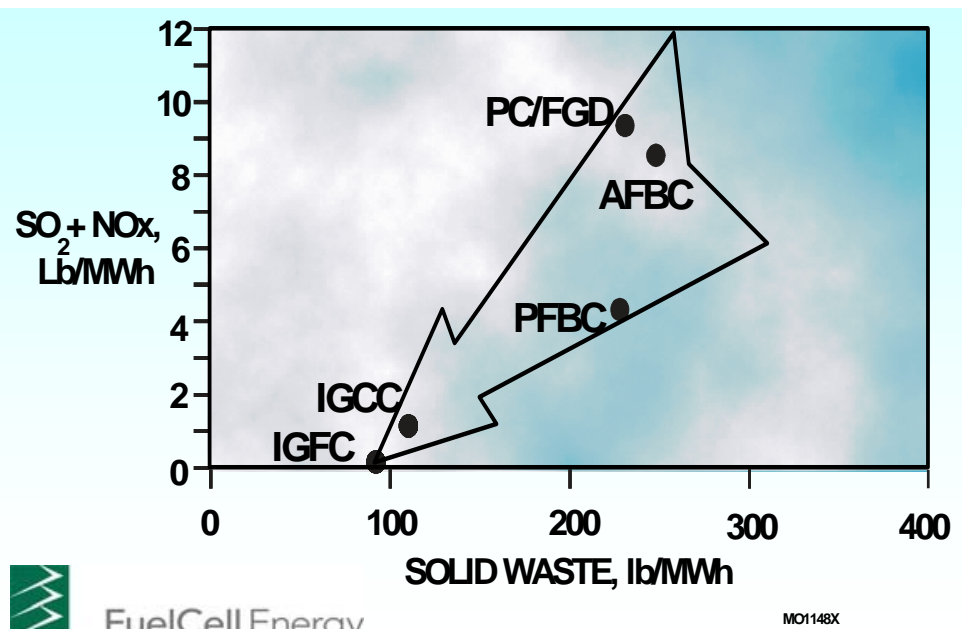

FuelCell Energy
Figure 3-2

Environmental Impact Comparison of IGFC and Other Technologies 
FuelCell Energy, Inc.

Final Report
Kentucky Pioneer Energy LLC, IGCC Project

2 MW Fuel Cell Demonstration

Cooperative Agreement DE-FC21-95MC31262

Subcontract KPE 2000-01

\subsection{PROJECT DESCRIPTION}

DOE selected the Clean Energy Demonstration Project led by Duke Energy in 1993 as a CCTDP Round V Project. The proposed 477 MWe IGCC included a carbonate fuel cell demonstration on a slipstream of the BGL gasification plant. The project was to be sited in Camden, New Jersey but was not initiated due to loss of the power purchase agreement. Other sites were investigated but resumption of the project was not achieved.

Kentucky Pioneer Energy (KPE) was selected by DOE in November 1999 to continue the IGCC project previously initiated by Clean Energy Partners Limited. The project was to be located in Trapp, Kentucky. The fuel cell demonstration project became part of the (KPE) IGCC project and was initiated in March 2000 with a subcontract from KPE.

In February 2003, FuelCell Energy and Kentucky Pioneer Energy agreed, with DOE approval, to relocate the fuel cell demonstration to the Wabash River Energy Ltd site, shown in Figure 4-1, in order to expedite the demonstration phase of the fuel cell power plant.

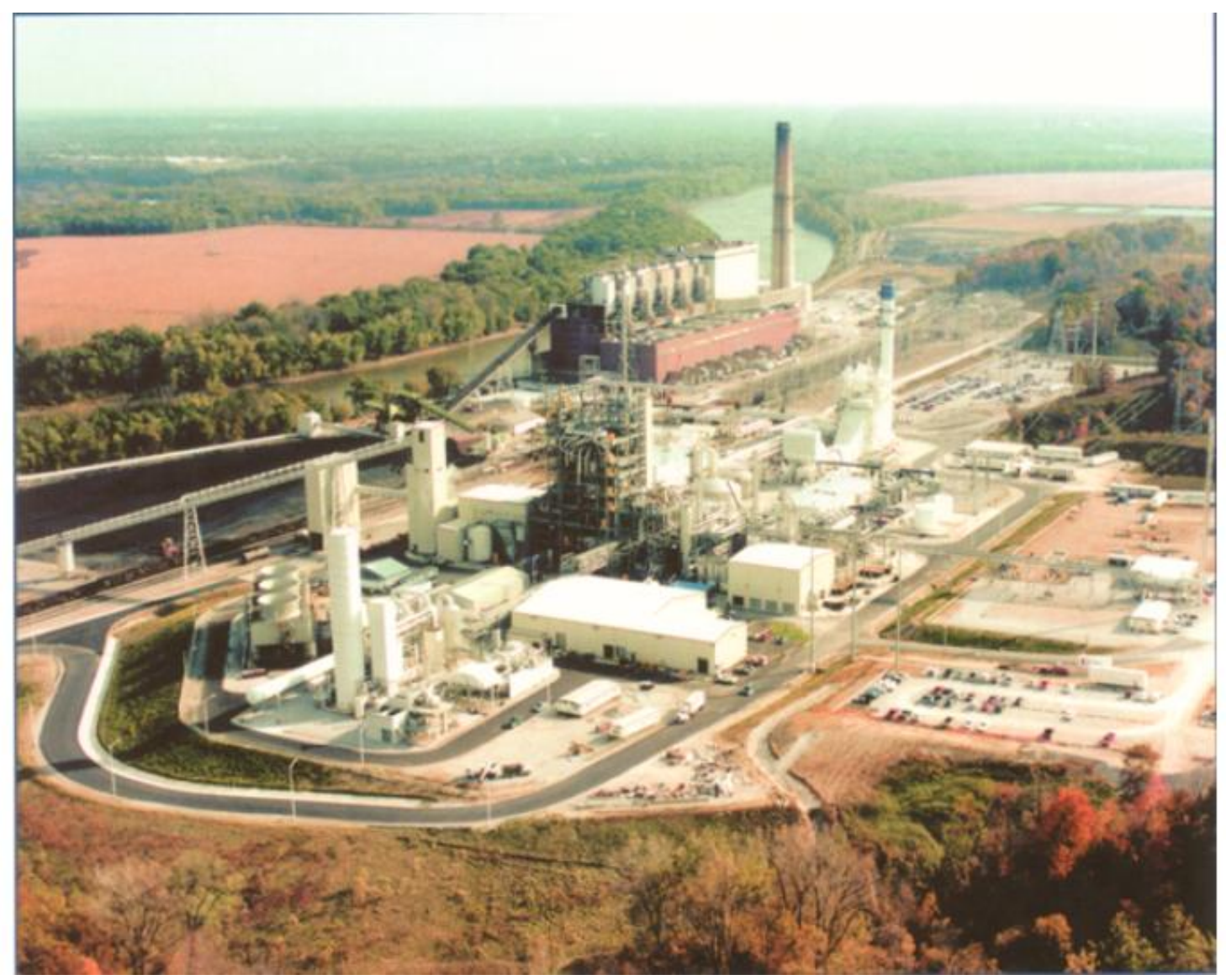

Figure 4-1. Wabash River Energy Ltd. Coal Gasification Site 
FuelCell Energy, Inc.

Final Report
Kentucky Pioneer Energy LLC, IGCC Project

2 MW Fuel Cell Demonstration

Cooperative Agreement DE-FC21-95MC31262

Subcontract KPE 2000-01

DOE had selected the Wabash River Project in September 1991 as a CCTDP Round IV Project. Construction was started in 1993 and commercial operation began in November 1995. The demonstration was completed in January 2000.

The Wabash River Project demonstrated the use of the Global Energy E-GAS ${ }^{\mathrm{TM}}$ coal gasification process. The design of the oxygen blown, continuous-slagging, two-stage, slurry fed, entrained flow gasifier was based on the Dow/Destec Louisiana Gasification Technology, Inc (LGTI) gasifier, originally tested at LGTI between 1987 and 1995, and is similar in size and operating characteristics. Particulate cleanup is by a hot metallic candle filter system, which was also tested at LGTI. Sulfur removal is by COS hydrolysis, a methyldiethanolamine (MDEA) acid gas removal system, and a Claus sulfur recovery unit. Prior to the COS hydrolysis unit the syngas is scrubbed to remove chlorides to protect the COS hydrolysis catalyst. High quality sulfur (>99.99\% pure) is recovered from the Claus unit in liquid form and sold for agricultural applications. The clean syngas is burned in a combined cycle GE MS7001 FA gas turbine unit that produces 192 MWe (gross), and the remainder of the power block consists of a Foster Wheeler HRSG, and a 1953 vintage Westinghouse reheat steam turbine. The steam turbine produces an additional $104 \mathrm{MWe}$ (gross). Parasitic power is $34 \mathrm{MWe}$, giving a total net power output of 262 MWe. The power plant was designed to operate on a range of local coals with a maximum sulfur content of 5.9\% (dry basis). Initial operation was on high-sulfur midwestern bituminous coal from the No. 6 seam at Peabody's Hawthorn Mine in Indiana. Alternative feedstocks including petroleum coke and blends of coal and coke were also tested. A typical analysis of the syngas produced is shown in Table 4-1. Sulfur content of the syngas was higher than indicated in Table 4-1, which is at maximum sulfur removal conditions of the amine system. Total sulfur in the desulfurized syngas was analyzed at $317 \mathrm{ppm}$.

\section{Table 4-1. Typical Product Syngas Analysis at the Wabash River Gasification Site ${ }^{16}$}

\begin{tabular}{|l|c|c|}
\hline Analysis & Typical Coal & Petroleum Coke \\
\hline & & \\
\hline Nitrogen, vol \% & 1.9 & 1.9 \\
\hline Argon, vol \% & 0.6 & 0.6 \\
\hline $\mathrm{CO}_{2}$, vol \% & 15.8 & 15.4 \\
\hline $\mathrm{CO}, \mathrm{vol} \%$ & 45.3 & 48.6 \\
\hline $\mathrm{H}_{2}$, vol \% & 34.4 & 33.2 \\
\hline $\mathrm{CH}_{4}, \mathrm{vol} \%$ & 1.9 & 0.5 \\
\hline Total Sulfur, ppmv & 68 & 69 \\
\hline HHV, Btu/SCF & 277 & 268 \\
\hline
\end{tabular}

\section{FUEL CELL POWER PLANT}

The 2 MW fuel cell power plant is a high temperature internally reforming carbonate fuel cell developed by FuelCell Energy. The carbonate fuel cell derives its name from its electrolyte, which consists of potassium and lithium carbonates. The carbonate fuel cell power plant was designed to operate syngas or on natural gas. Syngas from the Global Energy E-Gas entrained flow gasification plant clean-up system is further processed to make it suitable for the fuel cell 
FuelCell Energy, Inc. Final Report
Kentucky Pioneer Energy LLC, IGCC Project 2 MW Fuel Cell Demonstration Cooperative Agreement DE-FC21-95MC31262

Subcontract KPE 2000-01

power plant. The treated syngas is fed to the fuel cell to generate power. Figure 4-2 shows a schematic of the Wabash gasification plant with a slipstream feeding the $2 \mathrm{MW}$ fuel cell.

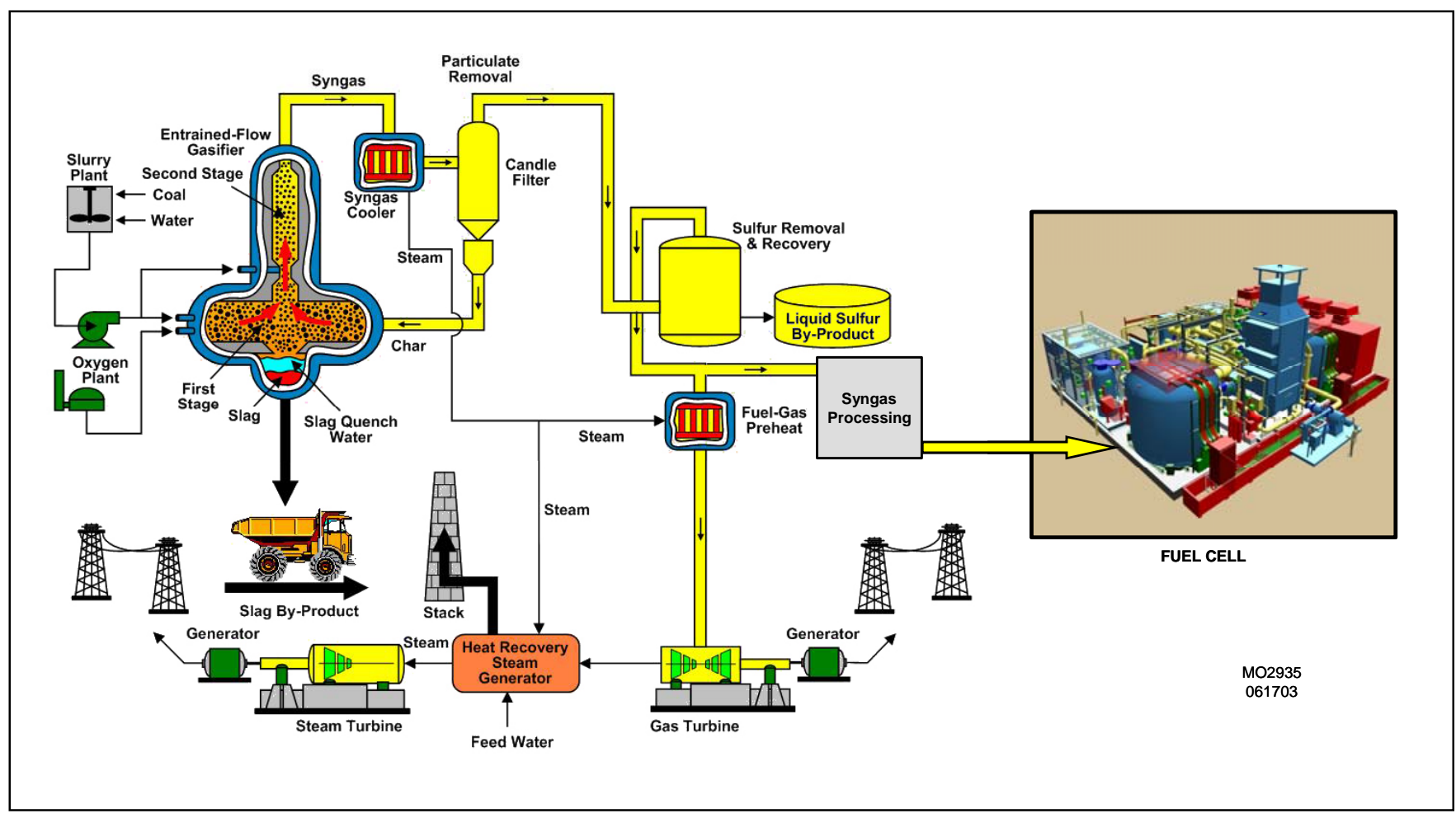

Figure 4-2. Simplified Process Flow Diagram of the Wabash River IGCC with Fuel Cell Operating on a Slip Stream

Source: DOE Project Fact Sheet (Modified to add the fuel cell)

\section{PROJECT PARTICIPANTS}

The participant in the CCTDP Round V Project was Kentucky Pioneer Energy (KPE). KPE planned to build the IGCC power plant and provide gas to a $2 \mathrm{MW}$ fuel cell power plant. FuelCell Energy, under subcontract to KPE was responsible for the design, construction and operation of the fuel cell power plant. Duke Fluor Daniel provided engineering design and procurement services for the balance-of-plant skids for the $2 \mathrm{MW}$ fuel cell power plant under subcontract to FuelCell Energy. Colt Engineering Corporation provided engineering design and fabrication/procurement of the syngas processing skids. FuelCell Energy manufactured the fuel cell modules at its Torrington, CT manufacturing facility. Jacobs Applied Technology provided the fabrication of the fuel cell module vessels. As mentioned previously in this section, FuelCell Energy and Kentucky Pioneer Energy agreed, with DOE approval, to relocate the fuel cell demonstration to the Wabash River Energy Ltd site in order to expedite the demonstration phase of the fuel cell power plant. The site operations conducted at Wabash River Energy Ltd (WREL) were conducted under an agreement signed between WREL and FuelCell Energy. 
FuelCell Energy, Inc. Final Report
Kentucky Pioneer Energy LLC, IGCC Project

2 MW Fuel Cell Demonstration

Cooperative Agreement DE-FC21-95MC31262

Subcontract KPE 2000-01

\subsection{FUEL CELL POWER PLANT DESCRIPTION}

A simplified flow schematic of the carbonate fuel cell power plant, which can operate on natural gas or syngas, is shown in Figure 5-1. Syngas from the Global Energy E-Gas entrained flow gasification plant clean-up system is further processed to make it suitable for the fuel cell power plant. The syngas is fed to the fuel cell power plant where methane is internally reformed and $\mathrm{CO}$ is shifted to $\mathrm{CO}_{2}$ and $\mathrm{H}_{2}$. Spent fuel exits the anode and is consumed in the anode exhaust oxidizer to supply oxygen and $\mathrm{CO}_{2}$ to the cathode. The resulting electrochemical reactions in the fuel cell anode and cathode produce DC power, which is inverted to AC. The cathode exhaust supplies heat to the fuel clean up and fuel moisturizer as it is vented from the plant. The exhaust gas is available for cogeneration to provide heating or cooling.

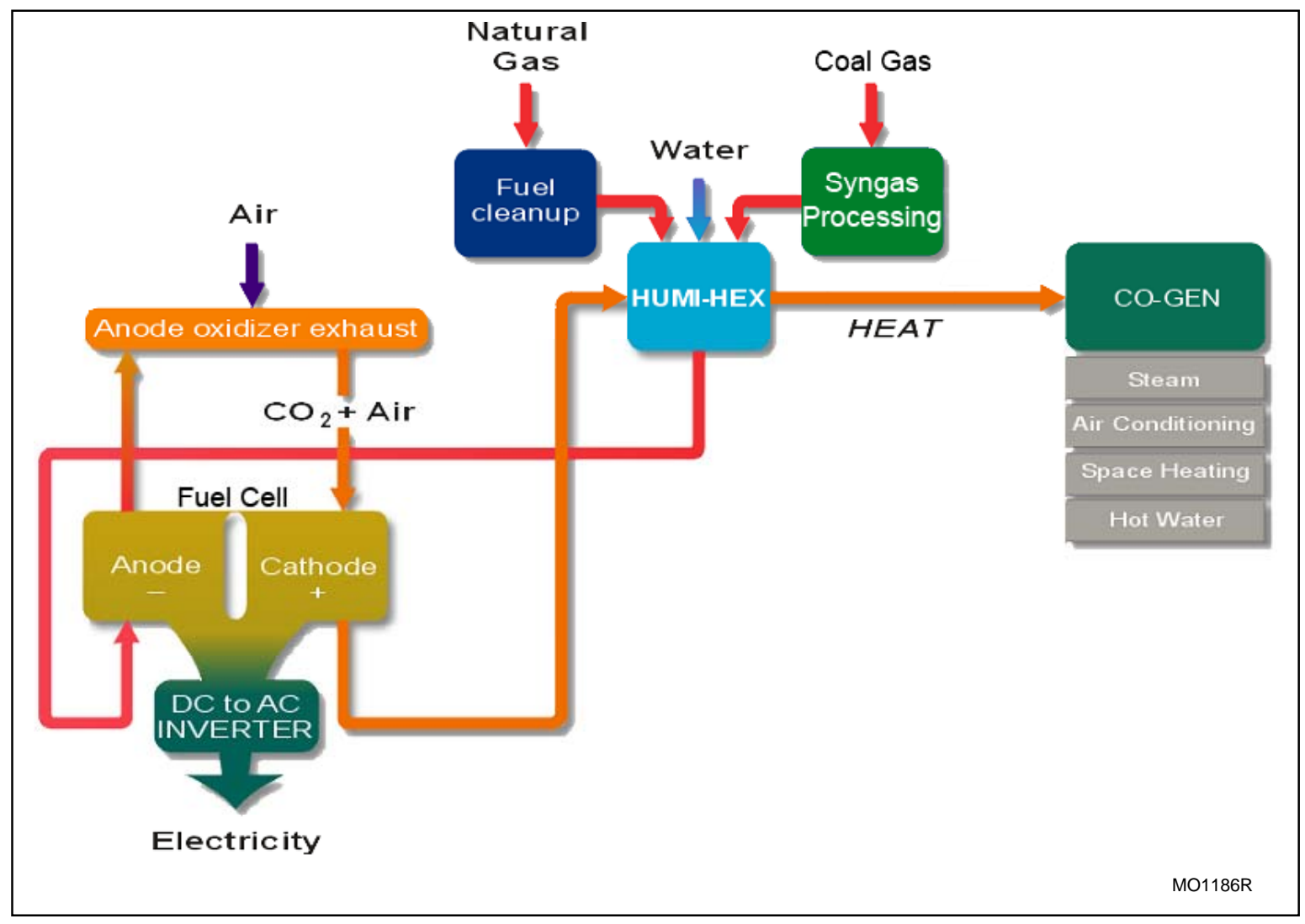

Figure 5-1. Carbonate Fuel Cell Power Plant Simplified Process Schematic

The carbonate fuel cell was selected for this demonstration on coal-derived syngas due to its availability in megawatt size and ability to utilize carbon monoxide (CO), a significant component of the syngas with a $45 \%$ typical composition when operating on coal. The lower temperature fuel cells such as phosphoric acid fuel cells and polymer electrolyte fuel cells are sensitive to carbon monoxide and require $\mathrm{CO}$ in the fuel gas to be reduced to part per million levels to avoid inhibiting electrode activity. The high temperature fuel carbonate fuel cell can operate with high levels of $\mathrm{CO}$ in the fuel gas. As $\mathrm{H}_{2}$ is consumed in the anode of the fuel cell, the $\mathrm{CO}$ reacts with water to produce additional $\mathrm{H}_{2}$ and $\mathrm{CO}_{2}$ according to the shift reaction 
FuelCell Energy, Inc. Final Report
Kentucky Pioneer Energy LLC, IGCC Project

2 MW Fuel Cell Demonstration

Cooperative Agreement DE-FC21-95MC31262

Subcontract KPE 2000-01

thereby utilizing the $\mathrm{CO}$ as a source of fuel. This feature makes the carbonate fuel cell suitable for operation on coal-derived syngas.

The 2 MW carbonate fuel cell power plant contains eight full-size carbonate fuel cell stacks. These were fabricated at FuelCell Energy's Torrington, CT manufacturing plant. Each group of four stacks is enclosed in one vessel. Two of these megawatt modules were fabricated for the plant installed at Wabash. After fabrication, these modules were conditioned and tested at FCE's conditioning facility in Danbury, CT shown in Figure 5-2. They were then shipped to the Wabash site in Terre Haute, Indiana. Figure 5-3 shows the plant installed at Wabash River Energy Ltd.

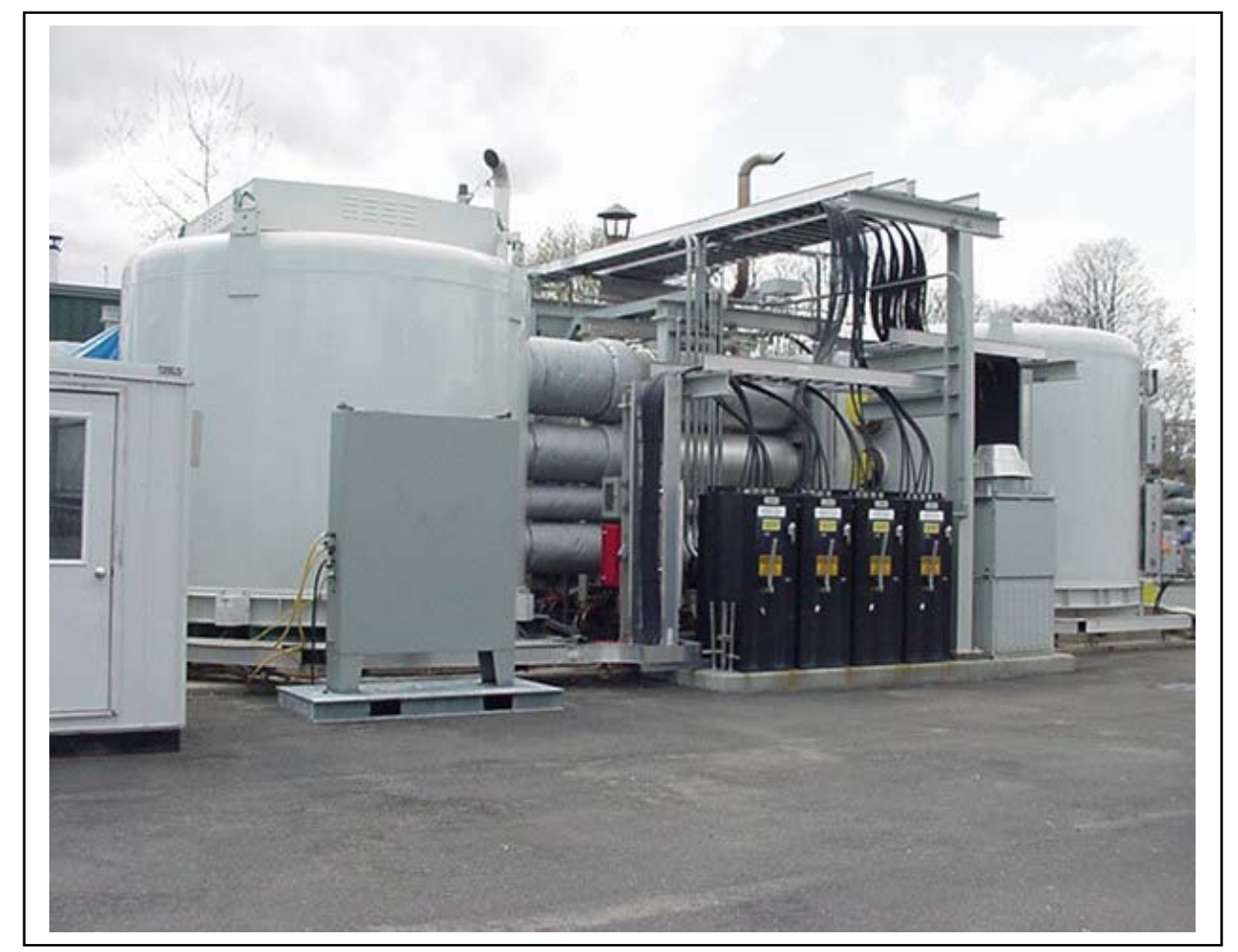

Figure 5-2. Conditioning of 1 MW Modules at FuelCell Energy

Two fuel cell modules, each housing four fuel cell stacks, produce the DC power. An inverter, including switchgear, converts the DC power to AC. The balance-of-plant (BOP) equipment includes fuel processing, thermal management, water treatment, instrument air system, and controls. Additional syngas processing equipment, shown to the left of the fuel cell power plant, is designed to make the syngas suitable for fuel cell operation. This includes final sulfur cleanup and methanation of the syngas. A summary of the major equipment is provided in Table 5-1. This includes the five fuel cell power plant skids, two fuel cell modules, and two syngas processing skids. 
FuelCell Energy, Inc.

Final Report
Kentucky Pioneer Energy LLC, IGCC Project

2 MW Fuel Cell Demonstration

Cooperative Agreement DE-FC21-95MC31262

Subcontract KPE 2000-01

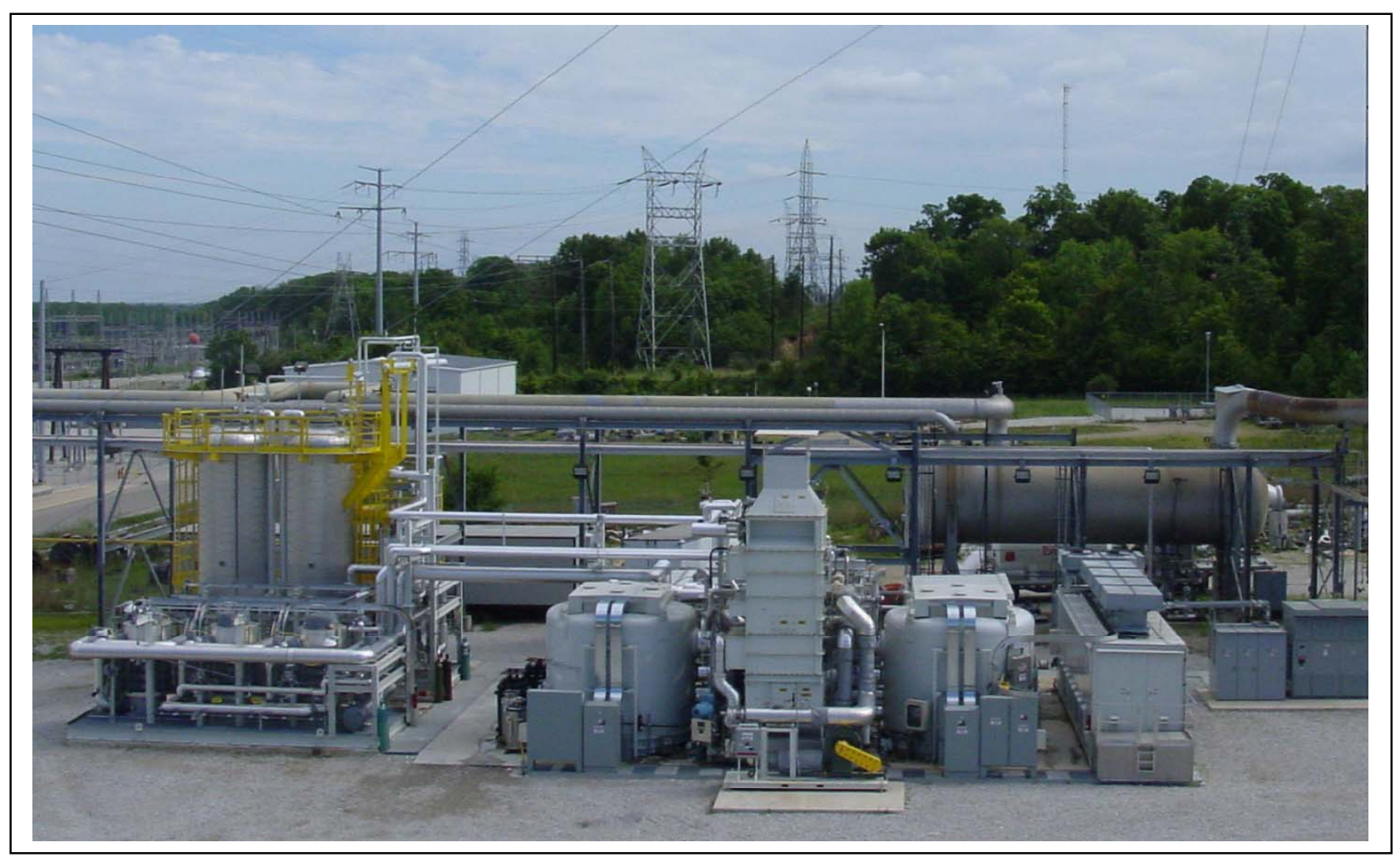

Figure 5-3. 2 MW Carbonate Fuel Cell Power Plant with Syngas Processing Skids Installed at Wabash

A process flow diagram (PFD) for the plant operating on syngas or natural gas is shown in Appendix A. Calculated syngas operation stream data for streams identified in the PFD is shown in Appendix B-1. Process flow diagrams and plot plan for the syngas treatment system are shown in Appendix C. Calculated performance for the fuel cell power plant on treated syngas with a heating value of $267 \mathrm{Btu} / \mathrm{std} \mathrm{ft}^{3}$ is shown in Table 5-2. This performance is for simple cycle operation. A combined cycle system with topping cycle using an expander to drop the gasified pressure and steam bottoming cycle was calculated to have an efficiency of $42.7 \%$ on syngas ${ }^{1}$.

${ }^{1}$ Assuming $25 \%$ efficiency for a bottoming steam cycle 
FuelCell Energy, Inc.

Final Report
Kentucky Pioneer Energy LLC, IGCC Project 2 MW Fuel Cell Demonstration Cooperative Agreement DE-FC21-95MC31262

Subcontract KPE 2000-01

Table 5-1. Summary of Major Equipment for the Fuel Cell Power Plant

\begin{tabular}{|c|c|c|}
\hline SKID & EQUIPMENT & PFD DESIGNATION \\
\hline CELL STACK & $\begin{array}{l}\text { FUEL CELL STACK MODULE } \\
\text { FUEL CELL STACK MODULE }\end{array}$ & $\begin{array}{l}300-V E-201 A \\
300-V E-201 B\end{array}$ \\
\hline NATURAL GAS FUEL TREATMENT & COLD GAS DESULFURIZER & 100-RR-201A/B \\
\hline \multirow[t]{5}{*}{ FCE2-SK1-001 } & NG DESULFURIZER AFTER FILTER & $100-F L-201$ \\
\hline & FUEL DEOXIDIZER & 100-RR-202 \\
\hline & PRECONVERTER & 100-RR-203 \\
\hline & PRECONVERTER AFTER FILTER & 100-FL-202 \\
\hline & NATURAL GAS HEATER & 100-HE-201 \\
\hline HRU/AGO & ANODE GAS OXIDIZER & 200-HF-201 \\
\hline \multirow[t]{4}{*}{ FCE2-SK2-001 } & AIR BLOWER & 200-BL-201 \\
\hline & EXHAUST GAS POLISHER & 100-HR-201-RR \\
\hline & FUEL HUMIDIFIER & 100-HR-201-HX-1 \\
\hline & FUEL SUPERHEATER & 100-HR-201-HX-2 \\
\hline WATER TREATMENT/ & WATER TREATMENT SYSTEM & 400-WT-201 \\
\hline INSTRUMENT AIR & INSTRUMENT AIR SYSTEM & \\
\hline \multicolumn{3}{|l|}{ FCE2-SK3-001 } \\
\hline START-UP BLOWR/HEATER & START-UP BLOWER & 200-BL-202 \\
\hline FCE2-SK4-001 & START-UP HEATER- & 200-HE-201 \\
\hline ELECTRICAL BALANCE & POWER CONDITIONING SYSTEM & \\
\hline OF PLANT & UPS SYSTEM & \\
\hline \multirow[t]{6}{*}{$600-E E-201$} & MOTOR CONTROL CENTER & \\
\hline & DISTRIBUTED CONTROL SYSTEM & \\
\hline & 480/208/120 VAC DISTRIBUTION & \\
\hline & HEAT TRACING CONTROL & \\
\hline & HVAC SYSTEM & \\
\hline & $A C \& D C B U S E S$ & \\
\hline \multirow[t]{6}{*}{ SYNGAS DESULFURIZER } & START-UP HEATER & 700-HR-201 \\
\hline & SYNGAS KD DRUM & 700-VE-203 \\
\hline & HYDROLYSIS REACTOR & 700-RR-201 \\
\hline & ABSORBER & 700-RR-202A \\
\hline & ABSORBER & 700-RR-202B \\
\hline & ABSORBER AFTER FILTER & 700-FL-205 \\
\hline \multirow[t]{5}{*}{ SYNGAS METHANATOR } & METHANATOR \#1 & 100-RR-203A \\
\hline & DESUPERHEATER \#1 & $100-H E-201 A$ \\
\hline & METHANATOR \#2 & 100-RR-203B \\
\hline & DESUPERHEATER \#2 & 100-HE-201B \\
\hline & METHANATOR \#3 & 100-RR-203C \\
\hline
\end{tabular}


FuelCell Energy, Inc. Final Report
Kentucky Pioneer Energy LLC, IGCC Project

2 MW Fuel Cell Demonstration

Cooperative Agreement DE-FC21-95MC31262

Subcontract KPE 2000-01

Table 5-2. Plant Design Performance on Syngas

\begin{tabular}{|lr|}
\hline Fuel cell DC power, kW & 1733.7 \\
Power conditioning loss, kW & 112.9 \\
Air blower loss, kW & 37.8 \\
Other parasitic losses, kW & 40 \\
Net AC Power , kW & 1543 \\
& \\
Power Plant Efficiency \%(LHV) & 37.19 \\
\hline
\end{tabular}

For comparison purposes, the performance of the plant on natural gas is shown in Table 5-3 and calculated stream data for natural gas operation is shown in Appendix B-2. A plot plan for the entire fuel cell power plant is shown in Appendix D.

Table 5-3. Plant Design Performance on Natural Gas

\begin{tabular}{|lr|}
\hline Fuel cell DC power, kW & 2293.2 \\
Power conditioning loss, kW & 149.3 \\
Air blower loss, kW & 79.1 \\
Other parasitic losses, kW & 40 \\
Net AC Power , kW & 2025 \\
& \\
Power Plant Efficiency \% (LHV) & 46.23 \\
\hline
\end{tabular}

\subsection{COST AND SCHEDULE}

The total cost of the $2 \mathrm{MW}$ fuel cell project was $\$ 37.5$ million, including design, construction, installation and pre-operation checkout. The DOE provided $\$ 17.3$ million (46\%) of the total cost. FuelCell Energy provided $\$ 20.2$ million or $54 \%$ of the total cost. Table 6-1 provides a breakdown of the project costs. The engineering design costs applies to the fuel cell power plant design. The syngas processing equipment costs includes engineering design of the syngas processing equipment.

The estimated/projected operating and maintenance costs anticipated at Wabash are shown in Table 6-2. The rates for syngas and utilities were negotiated with WREL as part of the site agreement between FCE and WREL. Estimated maintenance costs for the syngas treatment system include replacement of zinc oxide at six-month intervals. It is anticipated that in largescale applications sulfur removal can be more economically achieved with higher removal rates by the amine system reducing the burden on the final sulfur clean up system. The sulfur level provided by the Wabash plant for this fuel cell demonstration was approximately 300 ppm, making it necessary to incur significant additional expense for final sulfur removal. 
FuelCell Energy, Inc.

Final Report
Kentucky Pioneer Energy LLC, IGCC Project

2 MW Fuel Cell Demonstration

Cooperative Agreement DE-FC21-95MC31262

Subcontract KPE 2000-01

Table 6-1. Plant Cost Breakdown

\begin{tabular}{|l|r|r|}
\hline & & \multicolumn{1}{c|}{ Cost } \\
\hline Project Planning \& Administration & & $\$ 1,300,123$ \\
\hline Engineering Design & & \\
\hline & & \\
\hline Equipment Manufacturing \& Procurement & $\$ 20,722,680$ \\
\hline Two Fuel Cell Modules & $\$ 11,006,506$ & \\
\hline Natural Gas Fuel Treatment Skid & $\$ 249,002$ & \\
\hline Heat Recovery \& AGO Skid & $\$ 2,742,696$ & \\
\hline Water Treatment \& Instrument Air Skid & $\$ 468,068$ & \\
\hline Start-up Blower /Heater Skid & $\$ 110,314$ & \\
\hline Electrical Balance of Plant Skid & $\$ 2,774,709$ & \\
\hline Syngas Processor Equipment & $\$ 3,371,385$ & \\
\hline Site Design \& Construction & & \\
\hline Fuel Cell Power Plant & $\$ 2,962,878$ & \\
\hline Syngas Processor Assembly & $\$ 714,836$ & \\
\hline Construction Support & $\$ 365,069$ & \\
\hline Equipment Commissioning \& Systems Hot Testing & & \\
\hline Plant Removal & & $\$ 3,052,972$ \\
\hline Project Total & & \\
\hline
\end{tabular}

Table 6-2. Estimated Operation and Maintenance Cost

\begin{tabular}{|c|c|c|c|c|c|}
\hline & & \multicolumn{2}{|c|}{ 'Months } & \multirow[b]{2}{*}{12} & \multirow{2}{*}{$\begin{array}{c}\text { I year } \\
\text { Subtotals }\end{array}$} \\
\hline & 3 & 6 & 9 & & \\
\hline Syngas Fuel @ \$5.75/MMBTU & 127502 & $\$ 191,253$ & $\$ 191,253$ & $\$ 191,253$ & $\$ 701,261$ \\
\hline Natural Gas @ \$5.75/MMBTU & $\$ 68,564$ & $\$ 760$ & $\$ 760$ & $\$ 760$ & $\$ 70,844$ \\
\hline Water @\$0.13/100 gal & $\$ 866$ & $\$ 1,024$ & $\$ 1,024$ & $\$ 1,024$ & $\$ 3,938$ \\
\hline Nitrogen @\$1.47/1000 scf & 200 & 200 & $\$ 3,714$ & 200 & $\$ 4,314$ \\
\hline \multicolumn{6}{|l|}{ Planned Maintenance } \\
\hline 'Fuel Cell Plant & $\$ 3,200$ & $\$ 3,200$ & $\$ 3,200$ & $\$ 3,200$ & $\$ 12,800$ \\
\hline Syngas Treatment & $\$ 1,067$ & $\$ 1,600$ & $\$ 301,840$ & $\$ 1,600$ & $\$ 306,107$ \\
\hline \multicolumn{6}{|l|}{ Corrective Maintenance } \\
\hline 'Fuel Cell Plant & $\$ 9,640$ & $\$ 9,640$ & $\$ 9,640$ & $\$ 9,640$ & $\$ 38,560$ \\
\hline Syngas Treatment & $\$ 3,213$ & $\$ 4,820$ & $\$ 4,820$ & $\$ 4,820$ & $\$ 17,673$ \\
\hline Plant Operators & $\$ 91,182$ & $\$ 8,736$ & $\$ 8,736$ & $\$ 8,736$ & $\$ 117,390$ \\
\hline Equipment Rentals & $\$ 7,800$ & $\$ 7,800$ & $\$ 7,800$ & $\$ 7,800$ & $\$ 31,200$ \\
\hline Site services (Communications) & $\$ 6,500$ & $\$ 6,500$ & $\$ 6,500$ & $\$ 6,500$ & $\$ 26,000$ \\
\hline Subtotals & $\$ 319,734$ & $\$ 235,533$ & $\$ 539,287$ & $\$ 235,533$ & $\$ 1,330,087$ \\
\hline Cost $\$ / \mathrm{kWh}$ delivered & $\$ 0.086$ & $\$ 0.070$ & $\$ 0.160$ & $\$ 0.070$ & $\$ 0.096$ \\
\hline
\end{tabular}


FuelCell Energy, Inc.

Final Report
Kentucky Pioneer Energy LLC, IGCC Project

2 MW Fuel Cell Demonstration

Cooperative Agreement DE-FC21-95MC31262

Subcontract KPE 2000-01

The Cooperative Agreement between DOE and Kentucky Pioneer Energy was signed in November 1999. The subcontract between Kentucky Pioneer Energy and FuelCell Energy was signed in March 2000. Design activities were initiated in September 2000. Equipment purchase orders were initiated in November 2001. Construction of subsystems at major equipment vendors was initiated in December 2001. Fabrication of fuel cell modules was initiated in December 2002. Construction at the Wabash site was initiated June 2003. Fuel cell balance-of-plant equipment skids arrived at Wabash in July 2003. The fuel cell modules arrived at Wabash in May and June 2004. The syngas processing equipment arrived in May and installed in June. Pre-operation checks were completed in July 2004, however operations were put on hold on 7/19/04 due to lack of gas supply.

Table 6-3 compares the planned vs. actual dates for key milestones. The planned dates were estimated in April 2002. Power plant design for the balance of plant skids was $97 \%$ complete as of $12 / 31 / 02$, the target completion date, with skid construction already in progress. The design effort was completed by 1/31/03. Fuel cell stack module fabrication was significantly behind schedule, with two 1- MW modules completed, conditioned and ready for shipment to the site by 12/31/03. Some of the delay was due to a heater failure in the FCE fuel cell conditioning facility. Other factors included manufacturing priorities, manpower limitations, and additional modifications after conditioning. FCE took advantage of the time available while the syngas processing system was being built to make improvements in the fuel cell module. Operation of the fuel cell power plant on syngas was paced by the delivery and installation of the syngas processing skids, which were not ready until 6/30/04. The subcontract for the syngas processing system was issued in June 2003 and took one year to complete. While the syngas processing equipment was being manufactured, FCE chose to replace one fuel cell module (M10-4) with the next production module (M10-5) so that M10-4 could be used on another project. This change did not have a significant effect on the operating schedule since the syngas processing equipment was pacing.

\subsection{COMMERCIAL APPLICATIONS}

FuelCell Energy currently offers several carbonate fuel cell power plant products, the DFC300A, DFC1500 and DFC3000 (Figure 7-1), rated in capacity at $250 \mathrm{~kW}, 1 \mathrm{MW}$ and $2 \mathrm{MW}$, respectively, and are scalable for distributed applications up to $10 \mathrm{MW}$ or larger. These products are designed to meet the base load power requirements of a wide range of commercial and industrial customers including wastewater treatment plants (municipal, such as sewage treatment facilities, and industrial, such as breweries and food processors), telecommunications/data centers, manufacturing facilities, office buildings, hospitals, universities, prisons, mail processing facilities, hotels and government facilities, as well as in grid support applications for utility customers. As of September 2005, over 78 million kWh of electricity have been generated from power plants incorporating the Direct Fuel Cell (DFC) technology at over 40 customer sites throughout the world. 
FuelCell Energy, Inc. Final Report
Kentucky Pioneer Energy LLC, IGCC Project 2 MW Fuel Cell Demonstration Cooperative Agreement DE-FC21-95MC31262

Subcontract KPE 2000-01

Table 6-3 Comparison of Planned and Actual Completion of Key Milestones

\begin{tabular}{|lll|}
\hline & Planned & Actual \\
\hline & & \\
\hline Design Complete & $12 / 31 / 02$ & $1 / 31 / 03$ \\
\hline Fuel Cell Fabrication Complete & $12 / 18 / 02$ & $5 / 31 / 03^{1}, 7 / 31 / 03^{2}, 3 / 31 / 04^{3}$ \\
\hline Fuel Cell Conditioning and Test & $12 / 31 / 03^{4}, 4 / 30 / 04^{5}$ \\
\hline Balance of Plant (BOP) Fabrication Complete & $12 / 18 / 02$ & $6 / 30 / 03$ \\
\hline Site Prep Start & $6 / 03 / 02$ & $6 / 15 / 03$ \\
\hline Site Work Complete & $1 / 01 / 03$ & $10 / 31 / 03$ \\
\hline Fuel Cell Modules Shipped to Site & $2 / 15 / 03$ & $5 / 31 / 04$ \\
\hline Check Out Fuel Cell on Natural Gas & $5 / 14 / 03^{6}$ & \\
\hline Syngas Treatment System Installed & $9 / 16 / 03$ & $6 / 30 / 04$ \\
\hline Startup on Syngas & $10 / 09 / 03^{7}$ & \\
\hline Demonstration Complete & $10 / 04 / 04$ & $10 / 31 / 05$ (plant removed) \\
\hline Draft Final Report Submitted & $11 / 25 / 04$ & $11 / 09 / 05$ \\
\hline Approved Final Report Submitted & $1 / 25 / 05$ & $2 / 15 / 06$ \\
\hline
\end{tabular}

${ }^{1}$ For fuel cell stack module M10-3

${ }^{2}$ For fuel cell stack module M10-4

${ }^{3}$ For fuel cell stack module M10-5, which was used instead of M10-4

${ }^{4}$ For fuel cell stack module M10-3 and M10-4

${ }^{5}$ For fuel cell stack module M10-5

${ }^{6}$ Natural gas not available when needed for commissioning power plant (July 2004)

${ }^{7}$ Syngas not available when needed (after completion of natural gas testing estimated 09/07/04)

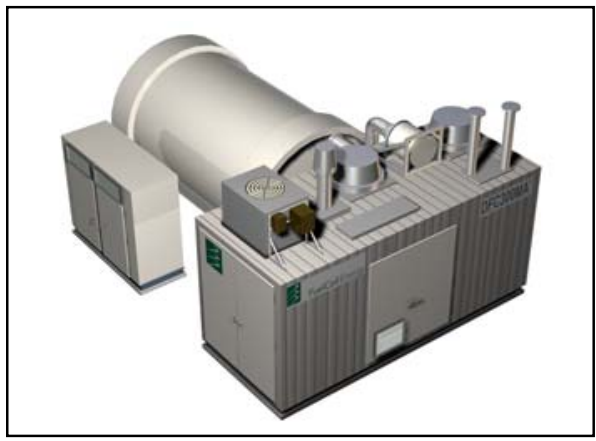

DFC300 MA

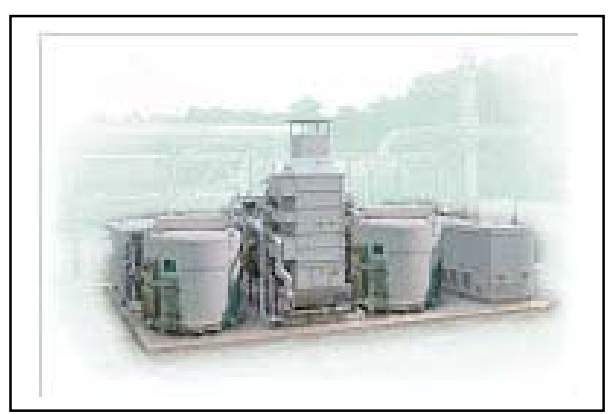

DFC 3000

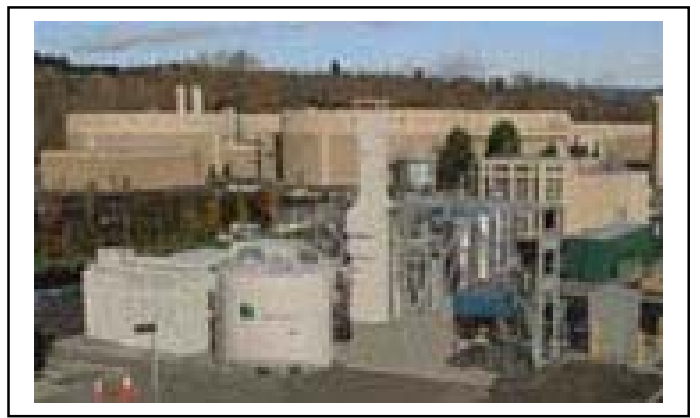

DFC1500

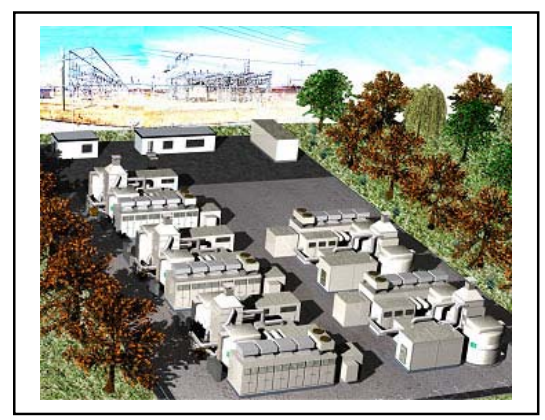

Multi MW Grid Support

Figure 7-1. Fuel Cell Power Plant Products Offered for Commercial Applications by FuelCell Energy 
DFC power plants provide the following advantages over conventional technologies:

- Higher operational efficiency. DFC power plants currently achieve electrical efficiencies of 45 to 47 percent (LHV) and have the potential to reach an electrical efficiency of 57 (LHV) percent at product maturity in single-cycle applications. In addition, DFC power plants can achieve overall energy efficiency of 70 to 80 percent for combined heat and power applications. This is greater than the fuel efficiency of competing fuel cell and combustion-based technologies of similar size and potentially results in a lower cost per $\mathrm{kWh}$ over the life of the power plant.

- Lower emissions. DFC power plants have significantly lower emissions of greenhouse gases and particulate matter than conventional combustion-based power plants. They emit virtually no $\mathrm{NO}_{\mathrm{x}}$ or $\mathrm{SO}_{\mathrm{x}}$ and have been designated "ultra-clean" by the California Air Resources Board (CARB). Comparative emissions of fuel cell power plants versus traditional combustion-based power plants as compiled by the DOE/National Energy Technology Laboratory and company product specification sheets are as follows:

$\begin{array}{lcc} & \text { Emissions (Lbs. Per MWh) } & \\ & \underline{\mathbf{N O x}} & \underline{\mathbf{S O}_{2}} \\ \text { Average U.S. Fossil Fuel Plant } & 4.200 & 9.210 \\ \text { Microturbine (60 kW) } & 0.490 & 0.000 \\ \text { Small Gas Turbine (250 kW) } & 0.467 & 0.000 \\ \text { Combined Cycle Gas Turbine } & 0.230 & 0.005 \\ \text { Fuel Cell, Single Cycle (DFC) } & 0.016 & 0.000\end{array}$

- Fuels flexibility. DFC power plants can utilize various fuel sources, such as natural gas, industrial and municipal wastewater treatment gas, propane, and coal gas (coal mine methane as well as syngas from coal gasification).

- Distributed Generation. The demand for reliable power, increasing concerns about the emission of harmful greenhouse gases and particulate matter, and the inability of central power generation systems to cogenerate heat and electricity, have created demand for new technologies that can provide clean, economic on-site generation. Consequently, projected demand for distributed generation is growing throughout the world. In October 2004, Energy User News reported that Allied Business Intelligence (ABI) projected distributed generation to the grid may increase to 200,000 MW worldwide by 2011 compared with 65,000 MW currently, with 6 percent or 12,000 MW from fuel cells. A year earlier, ABI reported that global stationary fuel cell cumulative shipments would rise from 55 MW cumulative through 2003 to nearly 18,000 MW cumulative through 2013, according to its moderate forecast.

\section{Global Markets}

FuelCell Energy is pursuing a strategy of global geographic penetration through strong strategic partners, which enabled the introduction of products in early adopter markets throughout the 
FuelCell Energy, Inc.

Final Report
Kentucky Pioneer Energy LLC, IGCC Project

2 MW Fuel Cell Demonstration

Cooperative Agreement DE-FC21-95MC31262

Subcontract KPE 2000-01

world. In selected regions, local market conditions, incentives and regulations have evolved which have enabled customers to purchase fuel cell power plants. These early adopters recognize the environmental and economic value of DFC power plants.

\section{Japan}

Japan's electricity prices are among the highest in the world. In addition, the government has strict emissions goals, following the Kyoto Protocol, which have resulted in the need to reduce emissions from the power-generating sector. Employing CHP technology is an important means to reduce carbon dioxide emissions, however, Japanese air pollution protection laws restrict installing and operating traditional generating technologies in urban areas. Since the Japanese Ministry of Environmental Protection has approved FuelCell Energy DFC power plants as meeting or exceeding all Japanese air pollution control laws, it is believed demand for DFC products will increase.

There are a number of other market drivers beyond strict emissions requirements that will stimulate demand for fuel cell power plants in Japan. First, a new regulation requires the use of wastewater treatment facilities for agriculture and farming. The Japanese government is subsidizing these new wastewater treatment facilities, including any power generation equipment that makes efficient use of "opportunity fuels" that result from wastewater treatment. Second, a National Renewable Portfolio Standard (RPS) for the power generation sector was adopted. The initial targets are approximately 3,500 MW by 2010. FuelCell Energy DFC products operating on anaerobic digester gas qualify under this standard. Third, a number of government-backed subsidy programs are available to DFC products, with incentives ranging from 35 percent to 55 percent of total eligible project costs. The aggregate annual budget by the various Japanese ministries for these programs total \$50 million. Fourth, the Japanese Ministry of Economy, Trade and Industry announced a new energy program with the goal of 2,200 MW of fuel cell power by 2010. FuelCell Energy’s Japanese partner, Marubeni Corporation, has been successful in working with various Japanese ministries to obtain approvals for broad siting flexibility to meet the growing demand for DFC products.

\section{Korea}

In 2004, fuel cells were identified as one of the 10 economic growth engines for the Korean economy and POSCO, the third largest steel producer in the world (see http://www.posco.com), was assigned by the Korean government to develop and commercialize large stationary fuel cell power plants. POSCO selected FuelCell Energy DFC products through Marubeni to pursue this effort. The Korean government's goal is to install 300 stationary fuel cell power plants, sized $250 \mathrm{~kW}$ to $1 \mathrm{MW}$, by 2012, and has designated \$1.6 billion to support this effort.

North America - U.S.

The U.S. is characterized by high electricity costs and grid-constraints in selected regions, such as California and the northeastern states such as New Jersey, New York, Connecticut and Massachusetts. The utility monopoly status is more entrenched in the U.S. than in other global 
FuelCell Energy, Inc.

Final Report
Kentucky Pioneer Energy LLC, IGCC Project

2 MW Fuel Cell Demonstration

Cooperative Agreement DE-FC21-95MC31262

Subcontract KPE 2000-01

markets, but developments that favor clean and efficient distributed generation such as fuel cell power plants are occurring. Existing programs are being renewed, and new initiatives are being implemented.

California has become a leader in regulatory policy. For example, DFC power plants have been certified to meet interconnection standards of investor owned electric utilities ("Rule 21"). In addition, DFC power plants meet the strict emissions requirement of the California Air Resources Board standard for 2007 ("CARB2007"), and have been designated as an 'ultra-clean' distributed generation technology. As a result, customers have access to certain incentive funding for the purchase of DFC power plants. In addition, customers who install and operate DFC power plants are exempt from exit fees and stand-by charges, saving them from paying fees of approximately $\$ .025-\$ 0.03 / \mathrm{kWh}$. End-users of fuel cell power plants are eligible to sell back unused power to publicly owned utilities during off-peak hours at wholesale or generation-based rates of approximately $\$ 0.04-\$ 0.05 / \mathrm{kWh}$. The California Self Generation Program provides $\$ 100$ million per year of incentive funding for 'ultra-clean' technologies on the basis of $\$ 2,500 / \mathrm{kW}$ for DFC products operating on natural gas and $\$ 4,500 / \mathrm{kW}$ for DFC products operating on renewable fuels such as anaerobic gas from wastewater treatment facilities.

FuelCell Energy was able to demonstrate the competitiveness of DFC products through this program in 2004. In fiscal year 2004, Alliance Power, an FCE partner, secured two customers through this program (City of Santa Barbara, 500 kW, and Sierra Nevada Brewing Co., $1 \mathrm{MW}$ ). Chevron Energy Solutions, another FCE partner, secured the first DFC1500 project in the State with the Santa Rita Correctional Facility in Alameda County, and, early in fiscal 2005, secured a $250 \mathrm{~kW}$ project for the San Francisco Mail Processing Facility. This program has been extended through 2007, enabling over $20 \mathrm{MW}$ of project funding per year.

In Connecticut, legislation was recently passed that will require the state's utility distribution companies to have $100 \mathrm{MW}$ of generation from renewable technologies contracted by mid-2007. The request for proposals for the first round (30 MW) was issued and project submissions (between $1 \mathrm{MW}$ and $15 \mathrm{MW}$ ) were due March 17, 2005. Final project selections are expected by the end of 2005. The Round 2 (30 MW) and the Round 3 (40 MW) selection process are expected to follow in succession. DFC power plants operating on natural gas are a Class I renewable technology and meet the eligibility requirements for this program.

Other states are also implementing policies to accelerate the installation of clean distributed generation technologies. For example, New York State exempts DFC power plants from standby charges if the installation represents less than 15 percent of the customer's maximum potential demand. In addition, the New York Public Service Commission adopted a renewable energy policy to increase electricity from renewable sources to 25 percent by 2013. To meet this requirement, it is estimated that New York State will need up to 3,700 MW of generation from renewable technology. DFC power plants operating on natural gas meet the renewable eligibility requirements in New York State. These renewable energy initiatives in Connecticut and New York may provide opportunities for large-scale multi-MW projects sized to 10-15 MW or larger. 
At the U.S. federal level, in addition to significant research and development funds that are received from the U.S. federal government, the U.S. Department of Defense Climate Change Fuel Cell Program grants funds to fuel cell power plant buyers, providing up to $\$ 1,000$ per $\mathrm{kW}$ of plant capacity (not to exceed one-third of total program costs). In fiscal year 2005, there is approximately $\$ 1.2$ million available for buyers of these fuel cell system incentive grants. Congress passed the Energy Policy Act of 2005 in July 2005, and it contains important incentives, including an investment tax credit of $\$ 1,000$ per $\mathrm{kW}$, for fuel cell power plant installations.

\section{North America - Canada}

FuelCell Energy's distribution partner, Enbridge Inc., is currently developing provincial relationships in Canada to have DFC products included in a portfolio approach to replace more than $100 \mathrm{MW}$ of coal and nuclear power plants and other projects with funding through the country’s Cdn\$250 million Sustainable Development Technology Program. Enbridge Inc. is the owner and operator of Canada's largest natural gas distribution company, Enbridge Gas Distribution, which provides natural gas to industrial, commercial and residential customers in Ontario, Quebec and New York State.

\section{Europe}

While electricity prices in Europe are not as high as they are in Japan and in the more expensive regions of the U.S., emphasis remains on reducing carbon dioxide emissions and grid-connected CHP projects are encouraged. The CHP Law, enacted in 2002, provides a €0.0511/kWh subsidy payable for 10 years for grid-connected CHP power plants, up to $2 \mathrm{MW}$. We estimate that this is the equivalent of a $\$ 1,000$ to $\$ 2,000$ per $\mathrm{kW}$ capital cost subsidy. In 2004, Germany's Renewable Energy Law opened up eligibility for fuel cells to receive up to $€ 0.20 / \mathrm{kWh}$, including a $€ 0.02 / \mathrm{kWh}$ premium over combustion-based technologies. RWE, Europe's largest investor owned utility, has invested in and has partnered with our German partner, MTU CFC Solutions GmbH, a DaimlerChrysler subsidiary. In a June 2003 report commissioned by World Wildlife Fund For Nature in co-operation with Fuel Cell Europe, it was reported that RWE expects 1,000 to 5,000 MW of German electricity demand to be supplied by distributed power by 2015 .

In the broader European market, the European Union has earmarked $€ 100$ million for research and demonstration projects for hydrogen and fuel cells through 2006.

\section{Target Applications}

FuelCell Energy products are designed to meet the base load power requirements of a wide range of commercial and industrial customers including wastewater treatment plants, data centers, manufacturing and industrial facilities, office buildings, hospitals, mission critical applications, universities and hotels, as well as in grid support applications for utility customers. Some specific markets we are targeting have substantial market potential as set forth in the table below.

Some specific applications of these representative applications include: 
FuelCell Energy, Inc.

Final Report
Kentucky Pioneer Energy LLC, IGCC Project 2 MW Fuel Cell Demonstration Cooperative Agreement DE-FC21-95MC31262

Subcontract KPE 2000-01

- Wastewater Treatment Plants. This application provides a unique opportunity because the methane generated from the anaerobic gas digestion process is used as fuel for the DFC power plant, which in turn generates the electricity to operate the wastewater treatment equipment at the facility. Wastewater treatment gas is considered a renewable fuel eligible for many government incentive funding for project installations throughout the world.

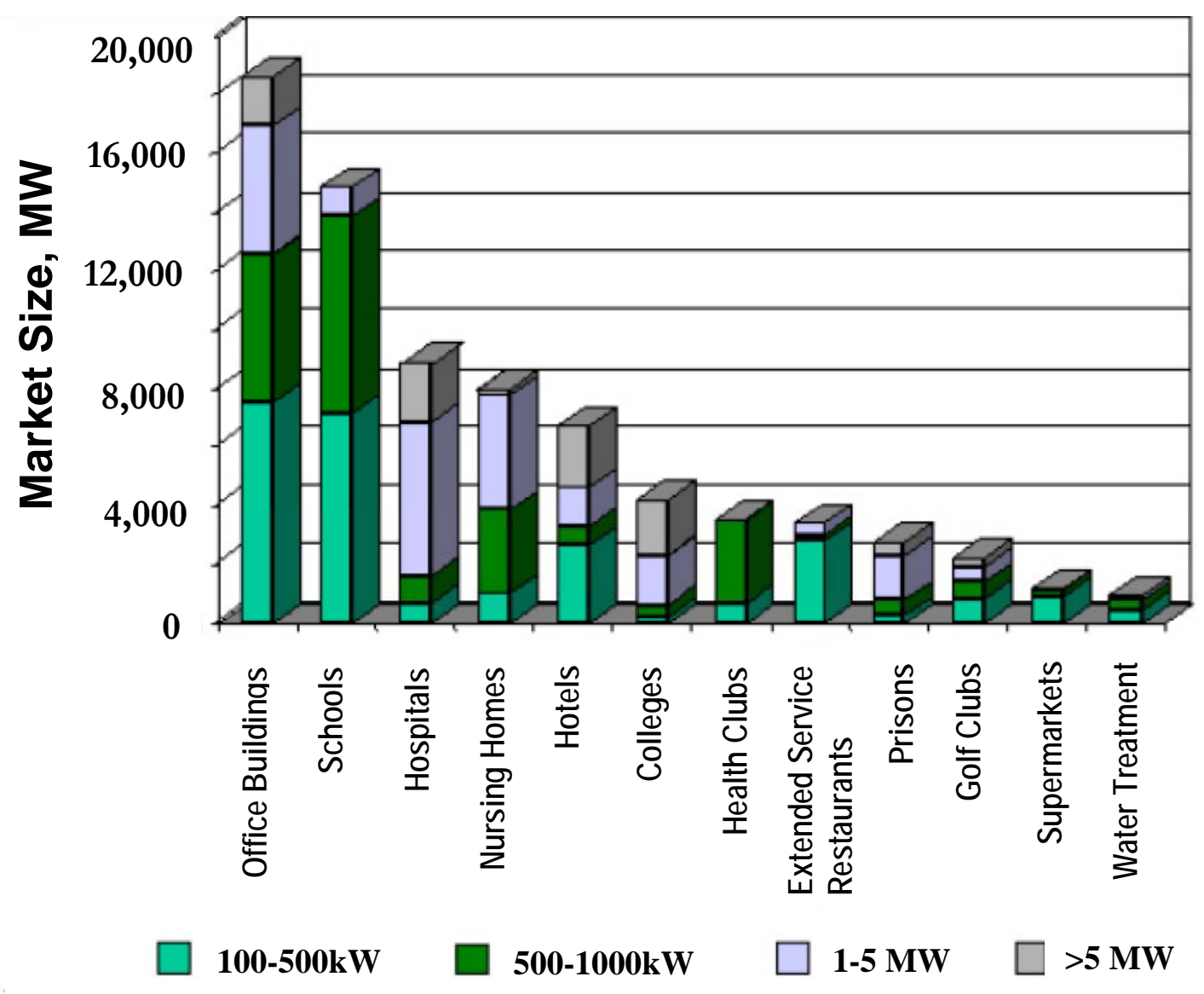

Source: DOE/Onsite Sycom Energy Corp., "The Market and Technical Potential for Combined Heat and Power in the Commercial/Industrial Sector,” January 2000 (Revision 1)

o Industrial. FuelCell Energy delivered its first commercially available DFC300A power plant to the Kirin Brewery in Japan in January 2003. In 2005, 1-MW of DFC power (4 DFC300A power plants) for a beer brewery at the Sierra Nevada Brewing Co. in Chico, California was installed and a 250-kW DFC300A power plant for a food recycling facility for Bioenergy Co. at Tokyo 'Super Eco Town' in Japan was installed.

o Municipal. FuelCell Energy began operating the first MW-class DFC1500 at the King County Wastewater Facility in Washington State on natural gas in 2004 that 
has now switched over to operation on anaerobic digester gas. In addition, FuelCell Energy installed 250-kW DFC300A power plants at the following municipal wastewater treatment facilities - the City of Fukuoka, Japan (through Marubeni Corp.), Terminal Island for the Los Angeles Department of Water and Power, Sanitation Districts of Los Angeles County, and the City of Santa Barbara.

- Hotels. The DFC 300A power plants at the 300-room Sheraton Edison and Sheraton Parsippany hotels in New Jersey provide each hotel with their $250 \mathrm{~kW}$ base load electricity requirements and 25 percent of their hot water needs. Our recently installed DFC300A power plant at the 1,750-room Sheraton New York Hotel and Towers in Manhattan provides approximately 10 percent of the electricity and hot water requirements.

- Institutional - Universities. At the Environmental Science Center near Yale University's Peabody Museum in New Haven, Connecticut, a DFC 300A power plant provides approximately 25 percent of the building's electricity needs, with the heat byproduct being used primarily to maintain tight temperature and humidity controls for its artifact storage facility. At the Michigan Alternative and Renewable Energy Center at Grand Valley State University in Muskegon, Mich., a DFC300A power plant is part of a comprehensive grid-independent energy system (includes solar panels and batteries for load following power requirements) that provides substantially all of the facility's base load electricity and uses the heat byproduct for heating and cooling. At Ocean County College in New Jersey, a DFC300A power plant provides 90 percent of the daily power requirements for three of the campus' buildings and 20 percent of the heating needs for six buildings.

- Institutional - Hospitals. MTU has provided its sub-MW carbonate fuel cell power plant, which incorporates FuelCell Energy DFC components, for a number of hospitals and clinics in Germany that supply electricity to the local clinic grid and the hot exhaust air is used to produce process steam for the facilities. Installations include the Rhon Klinikum Bad Neustadt (which completed its field trial in August 2004 after operating for more than 21,000 hours), Rhon Klinikum Bad Berka, Magdeburg Clinic and the Gruenstadt Clinic/Pfalzwerke.

- Industrial. MTU has installed its sub-MW carbonate fuel cell power plant for industrial CHP applications in Europe, such as a Michelin tire factory in Germany and an IZAR shipbuilding factory in Spain. Marubeni has installed two DFC power plants for an Epson factory in Japan and a natural gas gathering station at Japex, also in Japan. Caterpillar has installed and operated a DFC300A power plant at its technology center in Peoria, Illinois.

- Institutional - Telecommunications/Data Centers. MTU has installed a sub-MW carbonate fuel cell power plant for Deutsche Telecom in Munich, Germany that provides DC backup power for a telecommunications center. 
- Institutional - Prisons. FuelCell Energy announced its first one-MW DFC1500 power plant sale in California to Alameda County for the Santa Rita Correctional Facility in Dublin, Calif. This also was the first fuel cell project with the North American distribution partner, Chevron Energy Solutions, and was delivered in calendar year 2005.

- Grid Support. The Los Angeles Department of Water and Power has been a longstanding customer of FuelCell Energy, and operated one of the first field trial units. They have installed two separate DFC300 power plants that provide electricity to the grid - one at their corporate headquarters and one at another downtown location. In 2004, FuelCell Energy delivered a DFC300A power plant to a Westerville, Ohio substation facility for American Municipal Power-Ohio for its municipal distribution system. In 2005, FuelCell Energy delivered a DFC300A power plant for the Salt River project. This unit is located at the Arizona State University East Campus in Mesa, Ariz. and provides electricity to the local grid.

- Federal. FuelCell Energy is targeting the U.S. Government as an end-use customer for DFC products. Since the blackout of August 2003, there has been a growing interest by the government in increasing the reliability of power for mission critical applications. There is a DFC300A power plant installed at the Coast Guard Air Station Cape Cod in Bourne, Mass. that was sold through our North American distribution partner, PPL Energy Plus. FuelCell Energy's North American distribution partner, Chevron Energy Solutions, sold a 250-kW DFC300A power plant to the U.S. Postal Service's San Francisco Processing and Distribution Center that is expected to be delivered in calendar year 2005. The market for combined heat and power applications for federal facilities is estimated to be $1,590 \mathrm{MW}$.

\section{Cost Reduction}

Reducing product cost is essential for penetrating the market for high temperature fuel cell products. Cost reduction will reduce and/or eliminate the need for incentive funding programs that are currently available to allow product pricing to compete with grid-delivered power and other distributed generation technologies, and is critical to achieving and sustaining profitability. FuelCell Energy recognized this during the initial product development efforts leading up to our 2 MW Santa Clara 'proof-of-concept' project in 1996-1997. FuelCell Energy continued cost reduction and performance improvement efforts as it developed commercial designs for its products, incorporating lessons learned from this project, the $250 \mathrm{~kW}$ Danbury project in 1999 as well as the U.S. field trials with the Los Angeles Department of Water and Power and the Mercedes-Benz facility in Tuscaloosa, Alabama (project partnership with Southern Company Services, Inc., Mercedes-Benz U.S. International, the Alabama Electric Authority) in 2001-2002. Cost per $\mathrm{kW}$ was declining substantially during this period, from over $\$ 20,000$ per $\mathrm{kW}$ to approximately $\$ 10,000$ per $\mathrm{kW}$ at the start of commercial 'cost-out' program in mid-2003.

A value-engineering cost reduction program commenced in mid-2003 and is focused on reducing initial capital costs of the products as well as testing, conditioning, installation, operation and maintenance expenses. Further cost reductions are expected from increasing volume production 
FuelCell Energy, Inc.

Final Report
Kentucky Pioneer Energy LLC, IGCC Project

2 MW Fuel Cell Demonstration

Cooperative Agreement DE-FC21-95MC31262

Subcontract KPE 2000-01

above current levels. Product cost reduction comes from three areas - the 'field follow' program, the 'cost-out' program and the 'performance improvement' program. Engineers and scientists are dedicated to each area, but it is a collaborative effort that contributes to the overall serviceability, cost-reduction and performance improvement of the DFC products. An interdepartmental team was formed that regularly analyzes, verifies and tests value-engineering initiatives. Presently, approximately 20 percent of FCE employees are involved in this 'cost-out' program, including a staff of 20 engineers dedicated exclusively to this effort, and contributions are solicited and considered from the distribution partners, component suppliers, packaging engineering firms and directly from end-use customers. In addition, FCE expects to leverage the capabilities and resources of our distribution partners and key suppliers to enhance cost reduction efforts. These continuing efforts are expected to reduce material costs, simplify design, improve manufacturing yields, reduce product assembly labor and reduce production cycle time.

Selected examples of successful cost reduction initiatives include changing the material of our bipolar plates and reforming unit separators within our fuel cells, switching piping material, changing nitrogen purging methodologies in sub-MW product balance of plant, and substituting a standard shipping container for the custom-made balance of plant enclosure. FCE is building global sourcing capabilities for the most cost effective component and material supply.

FCE has achieved significant cost reductions since the program's inception. Product design changes are introduced in blocks rather than individually to minimize impact to manufacturing and to the customer. For example, in 2004 we reduced the cost of our DFC300A power plant by approximately 25 percent in two block changes. Block One changes were released into production beginning in late calendar year 2004 and block two changes will be implemented in products released for production in the summer of 2005.

Concurrent with field follow and cost-out programs, FCE continues to advance the performance of the core stack technology to increase power output and extend stack life. Increasing power output will reduce the initial capital cost per/kW and increasing stack life will reduce operation and maintenance costs to make FCE products even more competitive. Subscale testing of our carbonate fuel cells has successfully demonstrated an increase in power output. Efforts are underway to validate these advances in larger stacks before incorporating these improvements into commercial DFC products.

FCE reduced its product cost from over $\$ 20,000 / \mathrm{kW}$ with the $2 \mathrm{MW}$ Santa Clara `proof-ofconcept' project in 1996-1997 to the current manufactured design cost of approximately $\$ 4,300 / \mathrm{kW}$ on our MW class product and $\$ 4,600 / \mathrm{kW}$ for the sub-MW product. Reducing product cost is essential for FCE to penetrate the market for the high temperature fuel cell products. Cost reductions will lessen and/or eliminate the need for incentive funding programs that are currently available to allow fuel cell product pricing to compete with grid-delivered power and other distributed generation technologies, and are critical to FCE's attaining profitability.

In 2005, FCE introduced the DFC1500MA, a four-module version of the DFC1500 unit, which incorporates earlier cost reductions achieved on the DFC300MA. The modular architecture design not only provides cost savings for manufacturing, transportation and installation, but 
lower operating and maintenance expenses due to improved serviceability. Improved availability is also expected due to multiple, more easily replaceable stack modules. In addition, incorporating a multi-module design for the DFC1500MA introduces more standardization across all product lines. The prototype for the DFC1500MA is expected to be tested in mid-2006 with release for production planned for late-2006.

The sub-MW product represents the majority of FCE's DFC power plants installed or in backlog. In 2005, FCE continued to identify and implement cost reductions on the DFC300MA with emphasis on reducing material cost through value engineering and reducing labor cost through process improvement.

FCE continues to target annual cost reductions of 20 to 25 percent per year across all product lines. With the market demand shifting toward multi-MW projects as a result of emerging renewable portfolio standards (RPS), the focus in 2006 will be on cost reduction for the 2 MW DFC3000 power plant. With additional value engineering initiatives, FCE anticipates that it can reduce the cost of DFC3000 power plant to a range between $\$ 3,200 / \mathrm{kw}$ to $\$ 3,500 / \mathrm{kW}$ by the end of 2006 based on current production levels.

\subsection{FUTURE DEVELOPMENTS}

FuelCell Energy has been continuing development of fuel cell power systems with fuel cell/turbine hybrid systems, solid oxide fuel cells, and hydrogen co-production. These developments, although not part of the CCTDP project, are expected to achieve higher efficiencies, lower costs, and hydrogen co-production, which will benefit future coal powered fuel cell power plants.

\section{Direct Fuel Cell/Turbine Hybrid Systems}

FuelCell Energy is actively developing direct fuel cell/gas turbine hybrid systems, DFC/ ${ }^{\circledR}$, for generation of clean electric power with very high efficiencies. The gas turbine extends the high efficiency of the fuel cell without the need for supplementary fuel. Key features of the DFC/T system include: electrical efficiencies of up to $75 \%$ on natural gas ( $60 \%$ on coal gas), minimal emissions, simple design, reduced carbon dioxide release to the environment, and potential cost competitiveness with existing combined cycle power plants. FCE successfully completed subMW scale proof-of-concept tests (pre-alpha DFC/T hybrid power plant). The tests demonstrated that the concept results in higher power plant efficiency. A small packaged natural gas fueled sub-MW unit is being developed for demonstrations (alpha and beta units). Also, the preliminary design of a $40 \mathrm{MW}$ power plant including the key equipment layout and the site plan was completed.

The DFC/T system concept is schematically shown in Figure 8-1. The system includes a heat recovery unit (HRU) consisting of a series of heat exchangers arranged to maximize the heat recovery from the cathode exhaust gas. The HRU has a dual functionality of preparing the anode gas and, also, transferring a portion of system exhaust heat to the gas turbine air (in low temperature recuperator, LTR). The preparation of anode gas includes humidification of natural gas by the feed water, and preheating of the anode gas to the fuel cell operating temperature. 
FuelCell Energy, Inc.

Final Report
Kentucky Pioneer Energy LLC, IGCC Project

2 MW Fuel Cell Demonstration

Cooperative Agreement DE-FC21-95MC31262

Subcontract KPE 2000-01

The humidification process provides the steam needed for the reforming of natural gas. Typically a steam-to-carbon ratio of 2 and higher is required for steam reformation of natural gas to prevent carbon formation. The mixed fuel and steam are preheated to the temperature of about $550^{\circ} \mathrm{C}$ prior to entering the fuel cell anode. The methane in the natural gas is steam reformed in the direct carbonate fuel cell (internal reforming) to hydrogen, which is the primary fuel for the fuel cell.

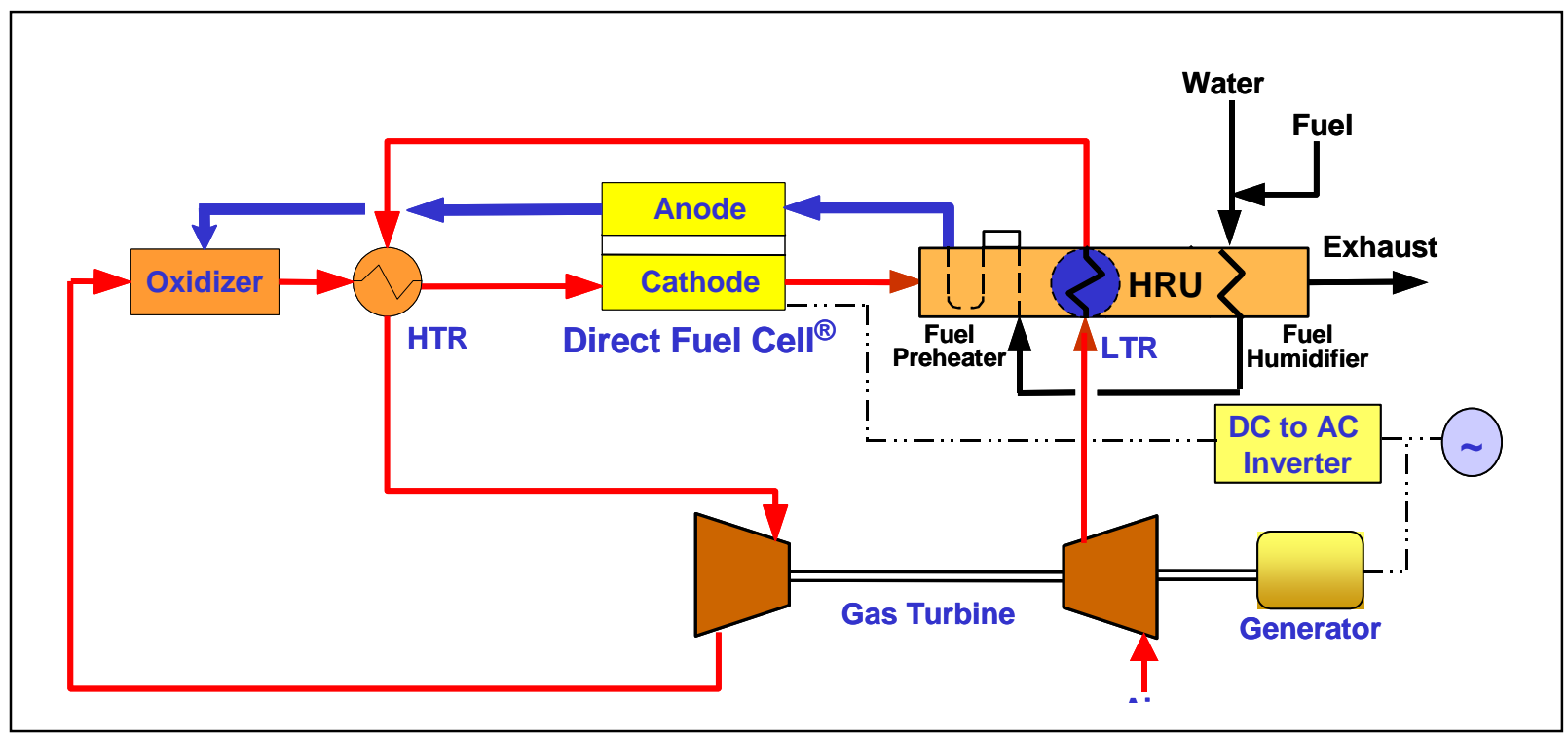

Figure 8-1. DFC/T ${ }^{\circledR}$ Ultra High Efficiency System Concept:

Fuel Cell Byproduct Heat Is Utilized In Gas Turbine To Supplement Fuel Cell Power

At the anode, hydrogen is electrochemically reacted producing DC electricity, and $\mathrm{CO}_{2}$ and water vapor as byproducts. The availability of water vapor at the anode as a product of electrochemical reaction helps drive the reforming reaction to completion and minimizes the need for feed water to the system. The anode exhaust containing some unreacted fuel is mixed with air and then oxidized completely in a catalytic oxidizer. In the turbine cycle, air is compressed to the operating pressure of the gas turbine and heated in the LTR using waste heat from the fuel cell. The compressed air is then heated further to the operating temperature of the gas turbine expander by a high temperature recuperator (HTR) located between the oxidizer and fuel cell (cathode). The hot compressed air is expanded in the turbine providing additional electricity. The expanded air then flows into the oxidizer. The oxidizer exhaust, containing excess air, flows into HTR, and subsequently into the fuel cell cathode. At the cathode, oxygen (in the air) and $\mathrm{CO}_{2}$ (from the anode exhaust) are reacted to complete the fuel cell electrochemical reaction. The heat generated in the fuel cell as the byproduct of the electrochemical reaction is utilized partly to support the endothermic (methane) reforming reaction. The thermal integration of the fuel cell electrochemical and methane reforming reactions offered by the internal reforming direct fuel cell enhances the fuel cell electrical efficiency while helping in the thermal management of fuel cell stack/module. The cathode exhaust, containing the heat from fuel cell, provides the heat for preheating the air (in LTR) and fuel, and for generation of steam in HRU before exiting from the power plant. 
FuelCell Energy, Inc.

Final Report
Kentucky Pioneer Energy LLC, IGCC Project

2 MW Fuel Cell Demonstration

Cooperative Agreement DE-FC21-95MC31262

Subcontract KPE 2000-01

\section{Multi-MW DFC/T Power Plant Design}

The baseline DFC/T configuration included a high temperature recuperator. The multi-MW power plant performance (power output and efficiency) estimates for the near, intermediate and long-term systems, based on this configuration, are presented in Table 8-1. For comparison, performance estimates for the DFC-only systems are also shown in the table. Based on the comparison, the integration of the fuel cell with turbine in a hybrid system offers significant improvement in power plant electrical efficiency. The mid-term and long-term estimates are both based on improved fuel cell performance expected with fuel cell developments. The long-term system, in addition, employs an advanced gas turbine featuring intercooling and reheat cycle that might be available with future gas turbine developments. Figure 8-2 shows the process flow diagram of the system. The long-term system has a potential to offer system electrical efficiency approaching 75\% (LHV natural gas).

Table 8-1. Multi-MW DFC/T Power Plant (Baseline Configuration) Performance Projections:

Hybrid System Has Potentially Significant Efficiency Gain Over DFC-only System

\begin{tabular}{|c|c|c|c|c|c|}
\hline \multirow[b]{3}{*}{ Fuel Cell: } & \multicolumn{2}{|c|}{ Near-Term } & \multicolumn{2}{|c|}{ Mid-Term } & \multirow{2}{*}{$\begin{array}{c}\text { Long-Term } \\
\text { DFC/T Hybrid } \\
\text { With Intercooled } \\
\text { \& Re-heat } \\
\text { Gas Turbine } \\
\end{array}$} \\
\hline & DFC & $\begin{array}{l}\text { DFC/T } \\
\text { Hybrid }\end{array}$ & $\begin{array}{l}\text { Improved } \\
\text { DFC }\end{array}$ & $\begin{array}{c}\text { DFC/T Hybrid } \\
\text { With Improved } \\
\text { DFC }\end{array}$ & \\
\hline & & & & & \\
\hline DC Power Out, MW & 12.0 & 12.0 & 16.8 & 16.8 & 33.5 \\
\hline AC Power Out, Gross, MW & 11.3 & 11.3 & 16.4 & 16.3 & 32.7 \\
\hline Gas Turbine: & & & & & \\
\hline Expander Power, MW & & $\begin{array}{r}7.9 \\
(5.3)\end{array}$ & & $\begin{array}{r}8.7 \\
(5.9)\end{array}$ & $\begin{array}{r}20.7 \\
(10.9)\end{array}$ \\
\hline Net AC Out, MW & & 2.5 & & 2.6 & 9.3 \\
\hline Air Blower Power, MW & (0.3) & & (0.3) & & \\
\hline Auxiliary Power Consumption, MW & (0.1) & (0.1) & (0.1) & (0.1) & $(0.2)$ \\
\hline Net Power Output, MW & 11.0 & 13.7 & 15.9 & 18.8 & 41.8 \\
\hline Efficiency, \% LHV Natural Gas & $49.9 \%$ & $62.0 \%$ & $57.0 \%$ & $67.0 \%$ & $74.6 \%$ \\
\hline
\end{tabular}




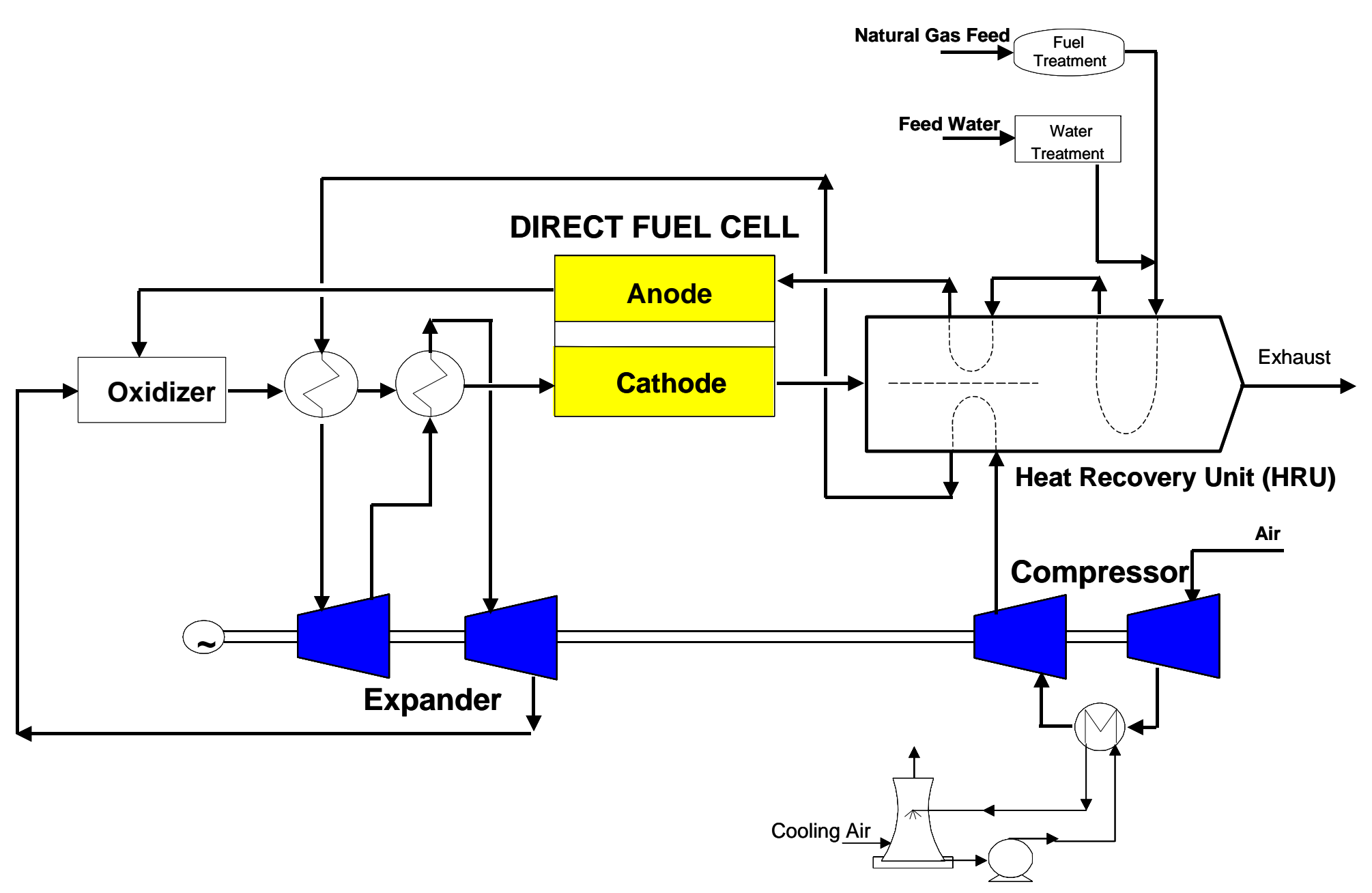

Figure 8-2. Process Flow Diagram Of The Long-Term Multi-MW DFC/T Hybrid System:

System Features an Advanced Gas Turbine With Intercooling and Re-heat Cycle 
FuelCell Energy, Inc.

Final Report
Kentucky Pioneer Energy LLC, IGCC Project

2 MW Fuel Cell Demonstration

Cooperative Agreement DE-FC21-95MC31262

The preliminary design of a $40 \mathrm{MW}$ power plant for near-term application was completed. The design is based on a scalable approach using FCE's existing M-10 (MW-scale) fuel cell modules in a cluster arrangement. The fuel cell cluster design has five M-10 modules in a cluster with common distribution piping for the fuel and oxidant gases. Based on the scalable overall plant design concept, the plant is arranged in three sections in addition to the centralized equipment. Each section consists of two clusters of fuel cell modules together with supporting equipment. The centralized equipment, which supports all three sections, includes a gas turbine, an anode gas oxidizer and other common site equipment such as a fuel clean-up subsystem and a water treatment subsystem.

The process flow diagrams with process controls for normal operation and start-up heating were generated. Steady-state mass and energy balances for the power plant were completed for various modes of operation; including start-up, standby, and full load operation. The performance of the $40 \mathrm{MW}$ power plant estimated based on near term fuel cell performance and a commercially available gas turbine is presented in Table 8-2. Specifications were prepared for key pieces of equipment and subsystems. Potential suppliers were contacted, and preliminary configuration information and cost estimates were obtained. The gas turbine selected for the $40 \mathrm{MW}$ plant design is a Man Turbo Model 1304-11. Man Turbo's THM heavy-duty gas turbine features a rugged industrial design. Key characteristics of the gas turbine include: pressure ratio of 8 and turbine inlet temperature of $1800^{\circ} \mathrm{F}$. The fuel clean-up subsystem is a centralized desulfurizer for the natural gas fuel, which uses activated carbon in an epoxy lined carbon steel vessel. Electrical one-line diagrams were prepared for the power generation and auxiliary power needs. The power conditioning system (PCS) is designed to convert the 300 VDC from the fuel cells to $13.8 \mathrm{kV}$ and is modular. A PCS module supports each fuel cell cluster. The $6000 \mathrm{~kW}$ modular unit is a packaged assembly that includes IGBT-based inverters and a step-up transformer.

Table 8-2. 40 MW DFC/T Hybrid Power Plant Performance (Estimate): An Electrical Efficiency Of 62\% Is Expected In A Near-term System

\begin{tabular}{|c|c|}
\hline Fuel Cell & \\
\hline DC Power Output, MW & 36.1 \\
\hline AC Power Output, MW & 34.3 \\
\hline Gas Turbine & 21.8 \\
\hline Expander Power, MW & $(10.4)$ \\
\hline Compressor Power, MW & 10.8 \\
\hline Net AC Power, MW & \\
\hline Plant Parasitic Load & $(3.6)$ \\
\hline Anode Gas Compressor, MW & $(0.8)$ \\
\hline Other Auxiliary Loads, MW & 40.8 \\
\hline Net Power Output, MW & 61.8 \\
\hline Efficiency, \% (LHV of Natural Gas) & \\
\hline
\end{tabular}


FuelCell Energy, Inc. Final Report
Kentucky Pioneer Energy LLC, IGCC Project

2 MW Fuel Cell Demonstration

Cooperative Agreement DE-FC21-95MC31262

The central control system for the plant is designed to coordinate the output of the three plant sections (six PCS modules). It provides operational sequence control for plant start-up heating, on-load operation, and normal and emergency shutdowns.

An overall layout/plot plan of the $40 \mathrm{MW}$ plant is shown in Figure 8-3. The site is approximately 273' x 325' in size. The arrangement of equipment on the site is designed to provide easy access to the equipment for maintenance and replacement, and minimize the length for the largest process piping. Design of the site arrangement included sizing of all the process piping and the development of process pressure profiles consistent with performance estimates. Thermal insulation requirements were established for all the process piping based on a surface touch temperature limit criteria. A computer model was developed for detailed design of the piping system including pipe sizes and insulation thickness requirements.

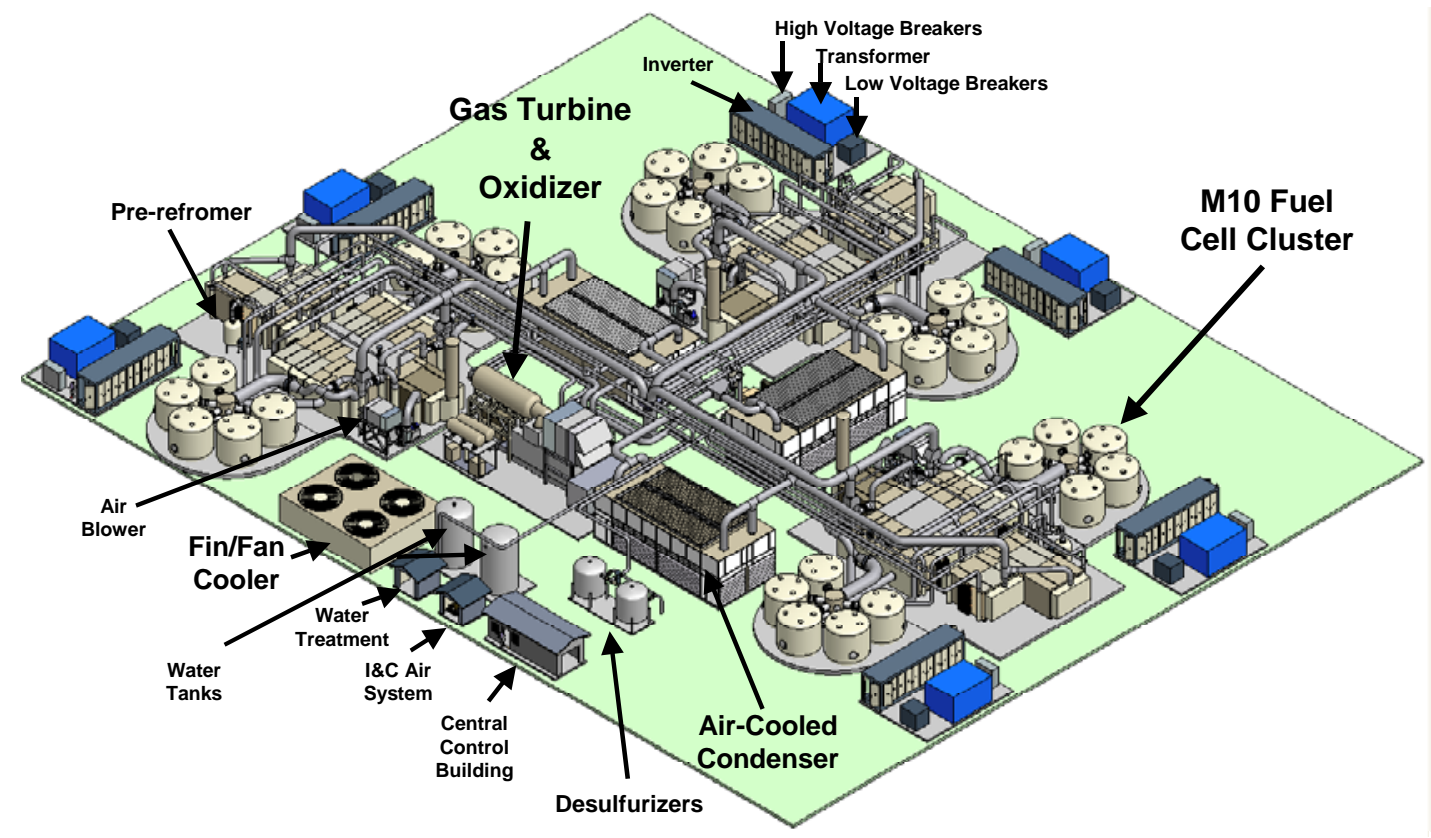

Figure 8-3. 40 MW Plant Layout/Plot Plan:

Power Plant Is Divided Into Three Sections, Each Containing A Pair Of Fuel Cell Module Clusters

\section{Solid State Energy Conversion Alliance (SECA)}

FuelCell Energy has been working with the United States Department of Energy (DOE) through a cooperative agreement with the National Energy Technology Laboratory (NETL) to develop a Thermally Integrated High Power Density Solid Oxide Fuel Cell (SOFC) Generator. Program objectives include developing a kilowatt-class power plant (3-10 kW) that runs on natural gas and, later, propane and diesel fuels. The program seeks to thermally integrate the entire power plant for higher efficiencies and significantly reduce the cost of manufacturing. 
FuelCell Energy, Inc.

Final Report
Kentucky Pioneer Energy LLC, IGCC Project

2 MW Fuel Cell Demonstration

Cooperative Agreement DE-FC21-95MC31262

Subcontract KPE 2000-01

Applications: Near-term market focus for the SOFC generator is stationary power. This includes telecommunication, on-site distributed generation of electricity and heat, etc. In the mid-term, these generators are suitable for auxiliary power units (APU), military and remote power application. In the long-term, these generators are suitable for coproduction of hydrogen and electricity as well as producing low-cost clean energy from coal and natural gas at multi-megawatt level.

Project Description: The project focuses on technology development for the overall SOFC system, individual components for cell, stack and

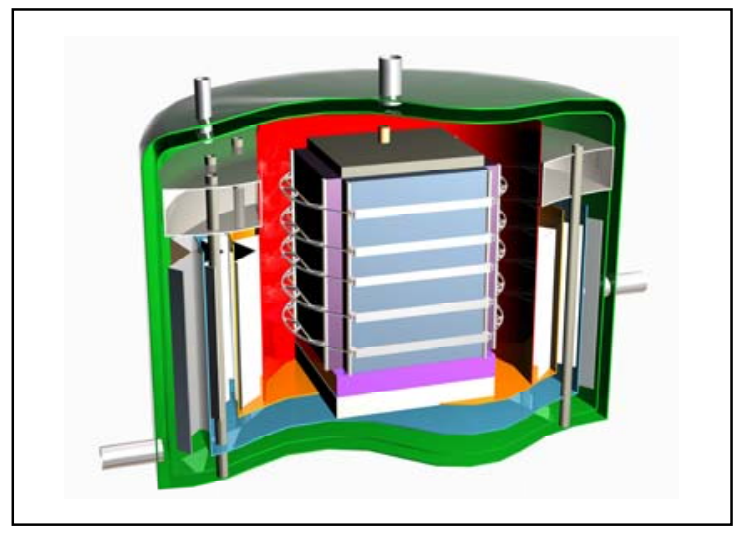

Schematic of Fully Integrated Advanced SOFC System other subsystems, as well as on cost reduction using mass production processes and automation for assembly. Successful development efforts will advance the current state of the art technology to the levels suitable for commercialization and to meet SECA performance goals.

The current technology development focus is on a baseline 3-kW SOFC system operating on natural gas in a grid-parallel mode. Concurrently, component development of an advanced 10-kW SOFC system is being pursued to further improve system efficiency (target: 45\%), expand market base and to reduce overall cost. The main emphasis is on thermal integration for high power density system operation and use of FCE's carbonate fuel cell power plants experience to guide the technology development efforts. In addition to the air-cooling, internal reforming and radiative heat exchange are being employed to improve system electrical efficiency, reduce number of components and overall cost. Research efforts are pursuing promising $R \& D$ paths to improve stack thermal management and durability, improve balance-of-plant components and materials for both performance and cost reduction, to develop

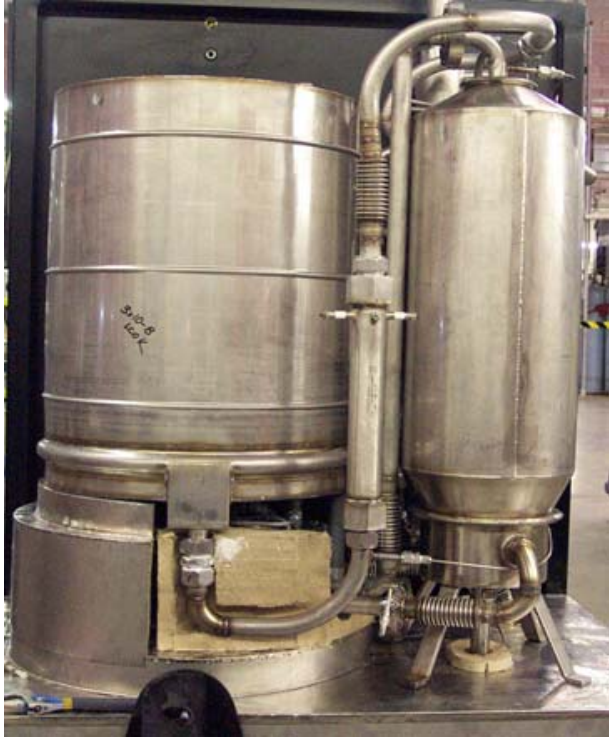

Natural Gas Fueled SOFC System In Operation at VPS process strategies for lower cost volume manufacturing and integrate appropriate new technologies into a prototype system capable of meeting SECA Program targets.

\section{Major Accomplishments:}

- $\quad$ Cell Technology: Operated a single cell on simulated fuel for 26,000 consecutive hours using low-cost metallic interconnects. 
FuelCell Energy, Inc.

Final Report
Kentucky Pioneer Energy LLC, IGCC Project 2 MW Fuel Cell Demonstration

Cooperative Agreement DE-FC21-95MC31262

Subcontract KPE 2000-01

- $\quad$ Stack Technology: Long-term stack tests for two different designs (Gen 4.1 and Gen 4.2) were performed with a cumulative operation for over 20,000 hours. An 80-cell tower was designed, built and operated. It produced $3.5 \mathrm{~kW}$-dc power and met the design targets. Further scale-up to 112-cell tower is in progress.

- $\quad$ System Technology: Designed, built and operated complete 2-kW systems on natural gas fuel (see above). The systems were operated in the grid-parallel mode for a cumulative operation of $>3,500$ hours with a peak electrical efficiency of $34 \%$. Testing of the $3-\mathrm{kW}$ baseline system on pipeline natural gas is in progress.

\section{Co-Production of Hydrogen}

Electrochemical hydrogen separation from fuel streams, including coal derived syngas, has been studied at FCE and continues to be under development. Figure 8-4 illustrates one of the concepts studied, which can be used to separate hydrogen from syngas.

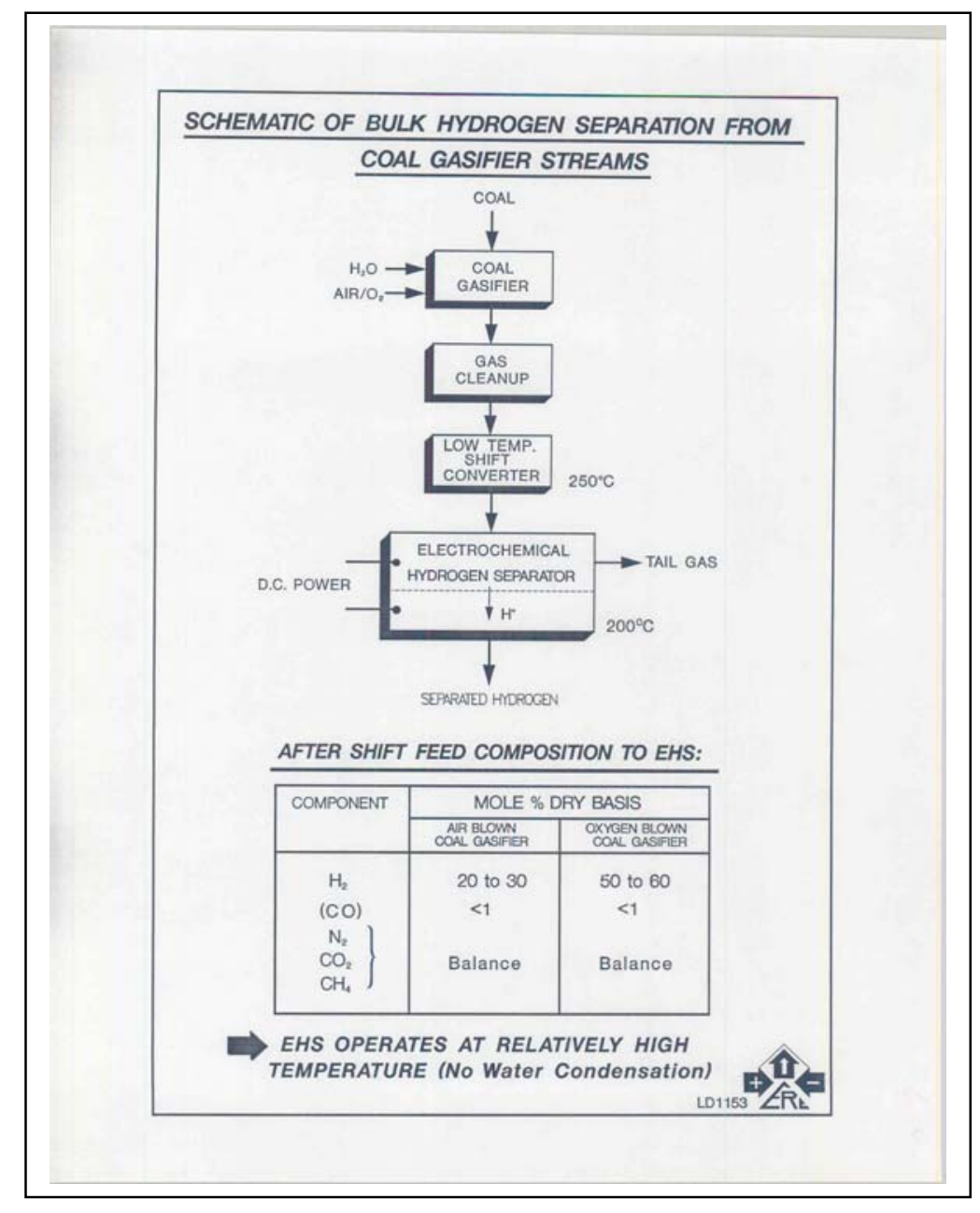

Figure 8-4. Schematic of Bulk Hydrogen Separation from Coal-derived Syngas 
FuelCell Energy, Inc.

Final Report
Kentucky Pioneer Energy LLC, IGCC Project

2 MW Fuel Cell Demonstration

Cooperative Agreement DE-FC21-95MC31262

Subcontract KPE 2000-01

\subsection{MARKET POTENTIAL}

U.S. power demand is expected to increase at a rate of $2 \%$ annually over the next twenty years. This growth will require about 400,000 MW of new capacity to be built during that period. In addition, the existing power plants will need to be replaced due to aging. This will further increase the need for the new power plants.

Based on the Direct Fuel Cell/Turbine (DFC/T) development at FCE a modified IGFC was conceived. This is based on using the DFC/T system as part of a coal based power plant. To differentiate between the IGFC system previously described and this new system, the new system is called an Integrated Gasification Hybrid Fuel Cell (IGHFC) system. The FCE approach to IGHFC power plant technology will continue to develop and evolve to the point where it will be competitive with other coal based options in the market for 100-500 MW power plants. The combination of high efficiency, superior environmental performance, and easy compatibility with $\mathrm{CO}_{2}$ capture and sequestration technology requirements are desirable characteristics for a coal-based power generating technology.

The approach that FCE has developed to the fuel cell section of the plant that combines gas cleanup and partial methanation to create a fuel stream that can be handled by its existing natural gas fueled DFC design is extremely important since it avoids the requirement for a parallel development program for a syngas compatible fuel cell. One of the unique features of the partial methanation approach is the improvement of overall efficiency of the power plant system.

The proposed approach of producing a standard syngas as fuel for the fuel cell allows the use of syngas made with any oxygen-blown gasifier from any coal. It can be adapted to any situation independent of location and coal type. Demand for the technology will depend on the competitiveness of its costs compared with other options to meet the specific electrical energy generation needs in that location. The proposed IGHFC system is versatile. It is suited for new power plants as well as retrofit markets. The market potential is $>1000 \mathrm{MW} /$ year as illustrated in this section.

\section{Market Evaluation}

FCE has performed several market assessment studies to evaluate the market potential for its DFC ${ }^{\circledR}$ fuel cell products and to develop a market-responsive product line. These studies were performed using help from independent market analysts, as well as direct surveys involving FCE's customer base. FCE's customer base included the Fuel Cell Commercialization Group (FCCG) with approximately twenty utility members and distributors. The overall response from these surveys indicates that the potential for fuel cells offering high efficiency at competitive prices is $>4,000 \mathrm{MW} / \mathrm{yr}$ for both submegawatt and MW-class units. A similar, multiple customer segment approach is proposed for the coal gas fuel cell markets (Table 9-1). These segments classify the potential markets into three different categories: 
Table 9-1. Summary Of Product Applications:

Three Different Categories are Identified

\begin{tabular}{|l|l|l|l|}
\hline Segment & Market Requirements & $\begin{array}{l}\text { Potential Size } \\
\text { Range }\end{array}$ & Fuel of Choice \\
\hline 1. IOUs and IPPs & $\begin{array}{l}\text { Low COE } \\
\text { Low Investment/MW } \\
\text { Moderate Fuel Efficiency } \\
\text { Low Emissions }\end{array}$ & 200-800 MW & Coal gas \\
\hline $\begin{array}{l}\text { 2. Rural Electric } \\
\text { Cooperatives }\end{array}$ & $\begin{array}{l}\text { Low COE } \\
\text { Moderate Investment/MW } \\
\text { High Fuel Efficiency } \\
\text { Low Emissions }\end{array}$ & $100-500 \mathrm{MW}$ & Coal gas \\
\hline $\begin{array}{l}\text { 3. In-plant Distributed } \\
\text { Generators }\end{array}$ & $\begin{array}{l}\text { Availability of waste fuels } \\
\text { High value for power } \\
\text { reliability and quality }\end{array}$ & 3-50 MW & $\begin{array}{l}\text { Hydrogen or CO } \\
\text { containing waste gas }\end{array}$ \\
\hline
\end{tabular}

Segment 1 Applications - Large-Scale IOU and IPP Central Station Power Plants, 200-800 MW

- This is the major market opportunity both in the U.S. and abroad for this technology as measured by the total demand for installed capacity.

- Because of the large amount of capital required for a single 200-800 MW project, these companies tend to be risk averse and will require sustained operation of a full-scale prototype or several early commercial projects before they commit to a unit.

- There may be some early adopters in this group who will be willing to accept/take some risk because of unique strategic need to add coal-fired capacity instead of natural gas fired capacity.

Segment 2 Applications - Intermediate-Scale Central Station Power Plants for Rural Electric Cooperatives (REC), 100-500 MW

- This group typically builds smaller central station plants than IOUs or IPPs. They serve smaller markets with lower population densities.

- This group may represent an opportunity for an early demonstration or small commercial plant because their cost of capital is substantially less than IOUs or IPPs. They can obtain $100 \%$ project financing at or close to U.S. treasury rates. In addition, they pay no income taxes. As a result, they can justify higher initial capital costs that provide high efficiency resulting in reduced operating costs for fuel. They also tend to be leaders in reducing emissions. 
FuelCell Energy, Inc.

Final Report
Kentucky Pioneer Energy LLC, IGCC Project

2 MW Fuel Cell Demonstration

Cooperative Agreement DE-FC21-95MC31262

Subcontract KPE 2000-01

- $\quad$ IGHFC appears to fit well with their needs.

Segment 3 Applications - Small-Scale Distributed Generation in Refineries and Chemical Plants where Syngas is Available, 3-50 MW

- The members of this group that may be interested in this technology will share a number of characteristics such as an available on-site supply of syngas or waste fuel gases containing a reasonable amount of hydrogen or carbon monoxide. This places a high value on a reliable supply of high quality electricity, technical sophistication, and may be able to accept early adopter risk levels.

- This group should include many refineries and chemical plants worldwide. The national security concerns may favor on-site power generation.

\section{Assessment of Technology Economics}

\section{Current Market Requirements for the Competitive Cost of Electricity}

Power generation technologies must be cost effective to compete for the current electricity market. Today's market for base load power is dominated by power supplied by existing conventional coal-fired and nuclear plants. Natural gas fueled combined cycles and gas turbines dominate the mid-range and peaking markets. For the past few years, almost all the power plants that have been built in the U.S. have been natural gas fired units. This trend has contributed to the recent upward pressure on natural gas prices resulting in current prices of over $\$ 5 /$ million Btu.

Recent studies of the relative investment costs of natural gas combined cycles, IGCC, and supercritical and ultra-supercritical pulverized coal units indicate that the price of product electricity dictates the relative market penetration of each technology The U.S. coal supply is much greater than natural gas and hence is anticipated to be more stable in price levels. The natural gas units will produce lower priced electricity than the coal units until natural gas prices exceed \$4.90/ million $\mathrm{Btu}^{28}$ (EPRI 2000). However, if $\mathrm{CO}_{2}$ emission limit legislation is passed where $90 \% \mathrm{CO}_{2}$ capture is required, the breakeven cost drops to about $\$ 3.40 /$ million Btu, while the breakeven costs for electricity from supercritical and ultra-supercritical pulverized coal units rises to about $\$ 5.75 /$ million Btu (EPRI 2000). These results clearly show that in view of the uncertainty of the future price of natural gas, coal based power generation based on a large supply of coal at low and relatively constant prices is a sound alternative for the future.

\section{$\underline{\text { Recently Projected Increases in the Market for Coal Fired Power Plants }}$}

The EIA Annual Energy Outlook 2003 predicted that the amount of coal-fired generation to be installed between 2001 and 2025 would total 74,000 $\mathrm{MW}^{2}$. The recent sustained levels of natural gas prices of more than $\$ 5 /$ million Btu has accelerated serious consideration of new base loaded coal-fired power plants instead of natural gas fired combined cycle power plants. A recent DOE 
FuelCell Energy, Inc.

Final Report
Kentucky Pioneer Energy LLC, IGCC Project

2 MW Fuel Cell Demonstration

Cooperative Agreement DE-FC21-95MC31262

Subcontract KPE 2000-01

publication $^{29}$ (DOE 2004) summarized in Table 9-2 along with the EIA data indicated that $61,000 \mathrm{MW}$ of new coal-fired plants are in various stages of consideration in a total of 36 states. The breakdown is presented in terms of the targeted in-service dates for these plants.

A review of both sets of data in Table 9-2 indicates acceleration, relative to EIA projections (EIA 2003), in the proposed in-service dates for these facilities. It should of course be noted that many of these proposed facilities, perhaps half, will never be built as can be implied by the fact that only 13,700 MW are currently in the operating, construction, or permitting phases. Currently, it is anticipated that most of these plants will be conventional subcritical or supercritical boilers. In areas where poor quality coals are available at low cost, CFB boilers may be installed.

Table 9-2. Expansion of Markets For Coal Fired Power Plants

\begin{tabular}{|l|l|l|l|l|l|}
\hline & $\begin{array}{l}\text { EIA 2003 } \\
\text { Forecast, } \\
\text { Thousands } \\
\text { of MW } \\
\text { (EIA 2003) }\end{array}$ & \multicolumn{5}{|c|}{$\begin{array}{c}\text { Proposed New Coal Fired Power Plants, } \\
\text { Thousands of MW } \\
\text { (DOE 2004) }\end{array}$} \\
\hline $\begin{array}{l}\text { In-service } \\
\text { date }\end{array}$ & & $\begin{array}{l}\text { Total } \\
\text { Proposed }\end{array}$ & $\begin{array}{l}\text { Now } \\
\text { Operating }\end{array}$ & $\begin{array}{l}\text { Under } \\
\text { Construction }\end{array}$ & $\begin{array}{l}\text { In } \\
\text { Permitting }\end{array}$ \\
\hline $2001-2005$ & 0 & 8 & 1.1 & 0.6 & 10.7 \\
\hline $2006-2010$ & 7 & 22 & & 1.3 & \\
\hline $2011-2015$ & 17 & 25 & & & \\
\hline $2015-2020$ & 22 & 6 (post & & & 10.7 \\
\hline $2021-2025$ & 28 & $2015)$ & & 1.9 & \\
\hline Total & $\mathbf{7 4}$ & $\mathbf{6 1}$ & $\mathbf{1 . 1}$ & & \\
\hline
\end{tabular}

IGCC plants have about the same projected COE as the other current approaches to coal-fired power generation including sub-critical and supercritical conventional and circulating fluidized bed boilers. However, the small efficiency advantage of 2-3 percentage points and lower emissions have not overcome the lack of operating experience and a slight premium in initial investment requirements of IGCC plants. Increasing emphasis on reducing emissions of $\mathrm{SO}_{\mathrm{x}}$, $\mathrm{NO}_{\mathrm{x}}$, particulate matter, and mercury may lead to IGCC technology capturing a significant share of the coal fired generation market over the next few years. Furthermore, increased efficiency and a much lower incremental cost of adding $\mathrm{CO}_{2}$ capture equipment may tip the balance in favor of IGCC if carbon taxes on $\mathrm{CO}_{2}$ emissions are introduced or $\mathrm{CO}_{2}$ emissions limits are introduced through legislation.

\subsection{CONCLUSIONS}

The 2 MW Fuel Cell Demonstration portion of the Kentucky Pioneer Energy IGCC project was designed to operate on coal-derived gas at the Wabash River Energy Ltd (WREL) coal 
FuelCell Energy, Inc. Final Report
Kentucky Pioneer Energy LLC, IGCC Project

2 MW Fuel Cell Demonstration

Cooperative Agreement DE-FC21-95MC31262

Subcontract KPE 2000-01

gasification site in Terre Haute, Indiana. The plant was built as modular skids, which were factory fabricated and shipped to the site. Two carbonate fuel cell modules rated at one megawatt each were fabricated, conditioned and shipped to the site for installation. A syngas processing system consisting of a desulfurization skid and a direct cooled methanation skid were designed, fabricated and installed at the site next to the $2 \mathrm{MW}$ fuel cell power plant. Figure 10-1 shows the complete power plant as installed at WREL.

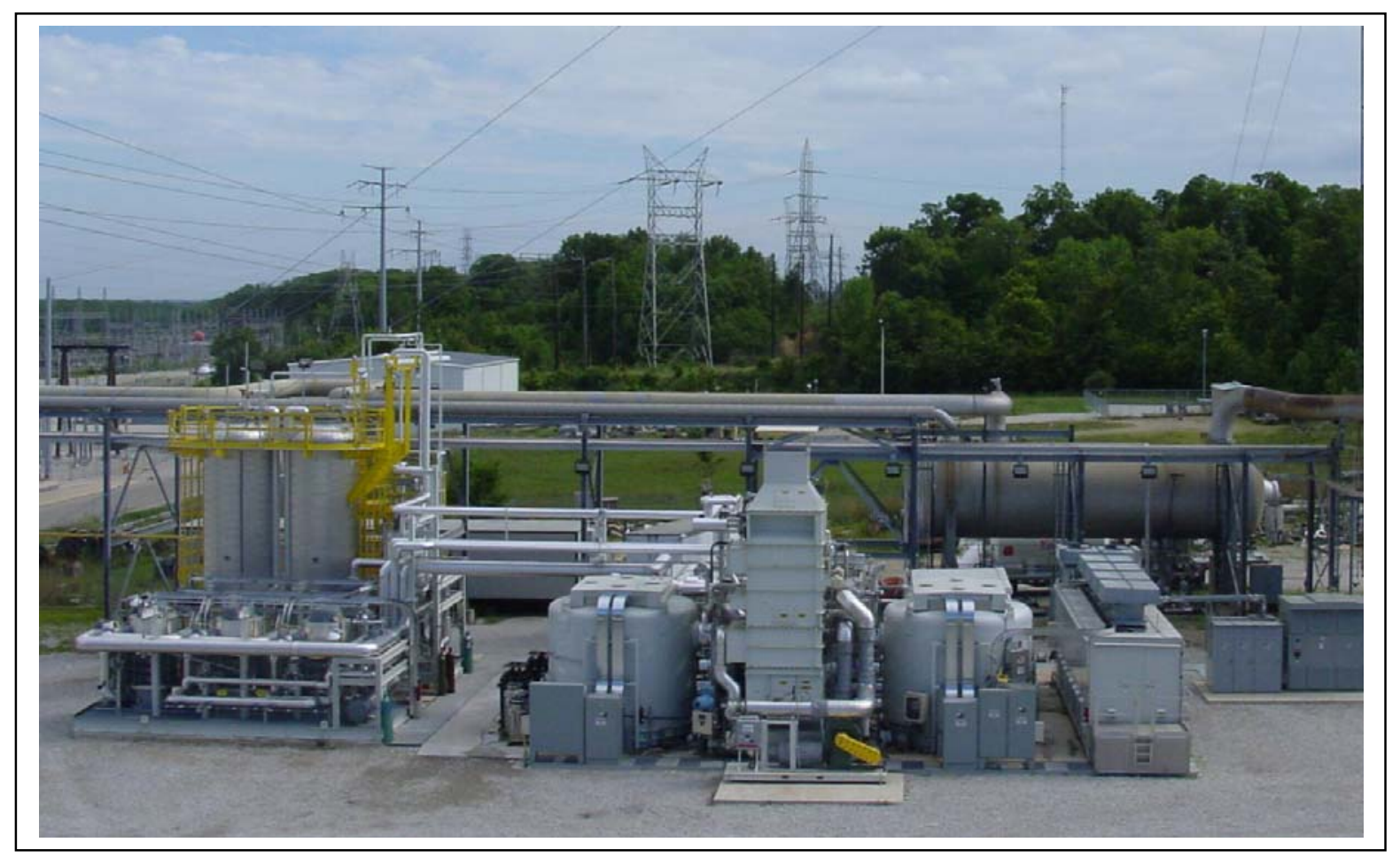

\section{Figure 10-1. 2 MW Fuel Cell Power Plant With Syngas Processing Installed At The Wabash River Energy Ltd Gasification Plant in Terre Haute, Indiana}

All required utilities were connected to the power plant, and syngas from the WREL gasification plant was piped to the syngas-processing skid. The power to be produced by the fuel cell power plant was connected to the WREL internal grid. All subsystems were checked out and were prepared for operation in July 2004. A test plan was prepared which included startup on natural gas and switching to syngas. Compared to the original schedule, the syngas operation was 11 months behind schedule. However, due to lack of availability of both natural gas and syngas at the WREL site, the fuel cell power plant was not able to operate. The fuel cell power plant was subsequently removed from the site and the site was restored by November 1, 2005.

Calculated performance indicated 37.2\% efficiency (LHV) on syngas. This was in simple cycle mode. Calculated combined cycle operation was estimated to achieve $42.7 \%$ efficiency on syngas not including the efficiency of the gasification plant. Compared to natural gas performance of $46.2 \%$ efficiency (LHV), the efficiency on syngas was about 9 percentage points 
FuelCell Energy, Inc.

Final Report
Kentucky Pioneer Energy LLC, IGCC Project 2 MW Fuel Cell Demonstration Cooperative Agreement DE-FC21-95MC31262

Subcontract KPE 2000-01

lower. In addition, the plant was derated by $23.8 \%$ in power due to the lower heating value of the syngas.

Future effort is needed to apply fuel cell turbine hybrids to coal systems to improve overall efficiency and to achieve the DOE goals for zero emissions, high efficiency coal powered plants. 


\section{BIBLIOGRAPHY}

1. Clean Coal Today, Office of Fossil Energy, U.S. Department of Energy, "World's

Largest Clean Coal-Powered Fuel Cell”, Issue No. 59, Fall 2004.

2. U.S. DOE/EIA “Annual Energy Outlook 2003 with Projections to 2025”.

3. Steinfeld, G, FuelCell Energy, "Comparative Analysis of a Fuel Cell Demonstration on Natural Gas vs. Coal Derived Syngas” April 30, 2002, Topical Report to Global Energy Inc. and U.S. Department of Energy, National Energy Technology Laboratory. Cooperative Agreement DE-FC21-95MC31262.

4. Steinfeld, G, "Integrated Gasification Fuel Cell (IGFC) Demonstration Test at the Wabash River Energy Ltd Gasification Site", $20^{\text {th }}$ Annual International Pittsburgh Coal Conference, September 15-19, 2003.

5. Farooque, M, G. Steinfeld, G. McCleary, S. Kremenik, "Assessment of Coal Gasification/Carbonate Fuel Cell Power Plants”, Topical Report to DOE/METC, June, 1990, DOE/MC/23274-2911. NTIS/DE90015579.

6. Sander, M.T., et al, Fluor Daniel, G. Steinfeld, Fuel Cell Energy, "Cost and Performance Analysis for a 220 MW Phased Construction Carbonate Fuel Cell Power Plant", $11^{\text {th }}$ Annual Conference on Gasification Power Plants, EPRI, October 1992.

7. Sandler, H.S., and S.J. Meyers, "Integrated Coal Gasification in Carbonate Fuel Cell Power Plants" $11^{\text {th }}$ Annual Conference on Gasification Power Plants, EPRI, October 1992.

8. EPRI, AFPS Developments, Gasification/Fuel Cell Study Projects Very Low Heat Rate, Winter 1990 Issue 6.

9. $\quad$ Meyers, S., Fluor Daniel, Advanced Molten Carbonate Fuel Cell Systems Using BGL Gasification, Presented at the $9^{\text {th }}$ Annual Conference on Gasification Power Plants, October 16-19, 1990, Palo Alto, CA.

10. Rastler, D.M., EPRI, C.G. Keeler, Dow Chemical USA, "Slip Stream Test of a 20 kW Carbonate Fuel Cell Unit at Destec’s LGTI GCC Facility”, Presented at the EPRI Gasification Conference, Oct 1993.

11. Kluttz D.E., Duke Engineering \& Services Inc., et al, "Proposed BGL CGCC Project for Clean Coal Technology Round Five Demonstration”, Presented at the EPRI Gasification Conference, Oct 1993. 
12. Steinfeld, G., W. Willson “Advanced Power System Featuring a Closely Coupled Catalytic Gasification Carbonate Fuel Cell Plant” Presented at the $17^{\text {th }}$ Biennial LowRank Fuels Symposium, May 10-13, 1993, St. Louis, Missouri.

13. Ghezel-Ayagh, H., R. Sanderson, A. J. Leo, "Ultra High Efficiency Hybrid Direct Fuel Cell/Turbine Power Plant”, Proceedings of Carbonate Fuel Cell Technology V, PV 9920, page 297-305, 190th Meeting of the Electrochemical Society, Oct. 7-22, 1999, HI.

14. DOE Fossil Energy TechLine, "Richardson Approves Federal Funding for High Tech, Ultra Clean Coal Plant in Kentucky”, U.S. DOE Press Release issued November 15, 1999.

15. DOE Clean Coal Technology, Compendium, Project Fact Sheet, Advanced Electric Power Generation Integrated Gasification Combined Cycle, Clean Energy Demonstration Project.

16. Clean Coal Technology, Topical Report Number 20, The Wabash River Coal Gasification Repowering Project, a 262 MWe Commercial Scale Integrated Gasification Combined Cycle Power Plant, An Update, September 2000.

17. FuelCell Energy Inc, Form 10-K for fiscal year ending 10/31/04, Annual Report submitted to the United States Securities and Exchange Commission.

18. H. Ghezel-Ayagh, A. J. Leo, and R. Sanderson, "High-Efficiency Fuel Cell System”, U.S. Patent No. 6,365,290, April 2002.

19. H. Ghezel-Ayagh, J. M. Daly, and Z. H. Wang, “Advances In Direct Fuel Cell/Gas Turbine Power Plants”, Proceedings of ASME/IGTI Turbo Expo 2003, ASME paper GT2003-38941.

20. Z. H. Wang and H. Ghezel-Ayagh, "Enhanced high efficiency fuel cell/turbine power plant”, U.S. Patent No. 6,896,988, May 24, 2005.

21. H. C. Maru and H. Ghezel-Ayagh, "Direct Carbonate Fuel Cell - Gas Turbine Combined Cycle Power Plant”, Presented in European Fuel Cell Forum, Lucerne, Switzerland, July 5-8, 2005.

22. H. Ghezel-Ayagh, J. Walzak, D. Patel, J. Daly, H. Maru, R. Sanderson, and W. Livingood, "Status of Direct Fuel Cell/Turbine Systems Development”, Fuel Cell Seminar 2004, San Antonio, Texas, November 1-5, 2004.

23. P. Patel, Thermally Integrated High Power Density SOFC Generator, SECA Annual Conference, Asilomar, CA, April 18-21, 2005. 
FuelCell Energy, Inc.

Final Report
Kentucky Pioneer Energy LLC, IGCC Project 2 MW Fuel Cell Demonstration Cooperative Agreement DE-FC21-95MC31262

24. B. Borglum, The Status of SOFC Development at Versa Power Systems, Solid Oxide Fuel Cell - IX, S.C. Singhal and J. Mizusaki, Editors, PV 2005-07, p. 89-97, The Electrochemical Society, Pennington, NJ, (2005).

25. Abens, S, J. Fruchtman, A. Kush, Development of an Electrochemical Hydrogen Separation System, AICHE 1992 Annual Meeting, September 3, 1992.

26. Abens, S., M. Farooque, Apparatus for Purifying Hydrogen, Patent No. 4,620,914, November 4, 1986.

27. Patel, Pinakin, Fuel Cell System, Patent No. 4,791,033, December 13, 1988.

27. Abens, S., M. Farooque, A. Kush, Novel Electrochemical Hydrogen Separation Device Using Phosphoric Acid Membrane Cell, Separation Science and Technology, 25 (13-15), pp 1361-1373 (1990).

28. Evaluation of Innovative Fossil Fuel Power Plants with $\mathrm{CO}_{2}$ Removal; EPRI Report 1000316 December 2000.

29. Tracking New Coal Fired Power Plants Presentation 5/18/2004 by DOE http://www.netl.doe.gov/coalpower/oces/pubs/ncp.pdf 


\section{Appendix A}

\section{Fuel Cell Power Plant Operating on Syngas}

\section{Process Flow Diagram}




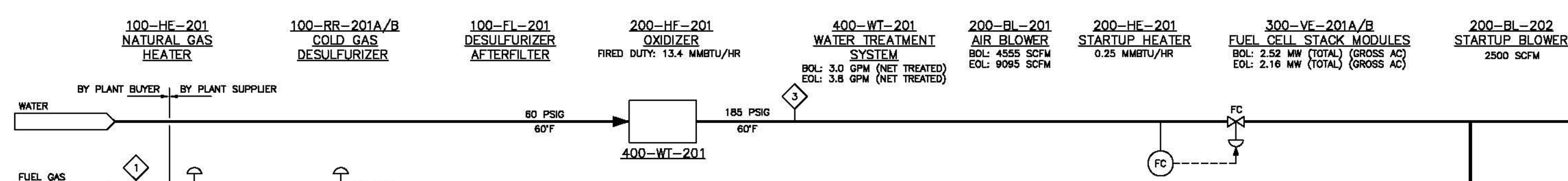

c rue as $\frac{100-H E-201}{(N 015)}$ (10)

Nrreocen (rapio vuges)
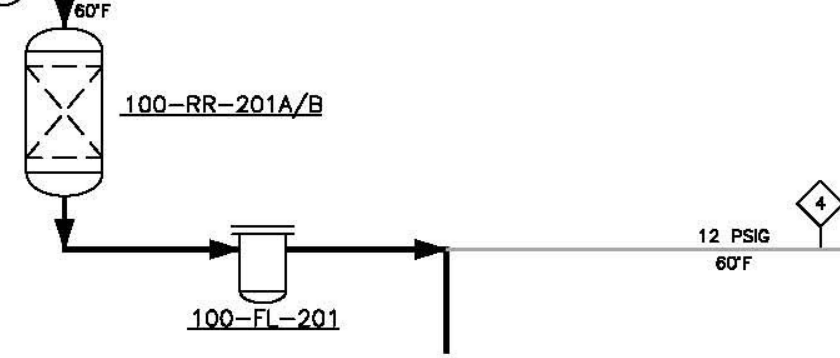

$\hat{\varphi}$

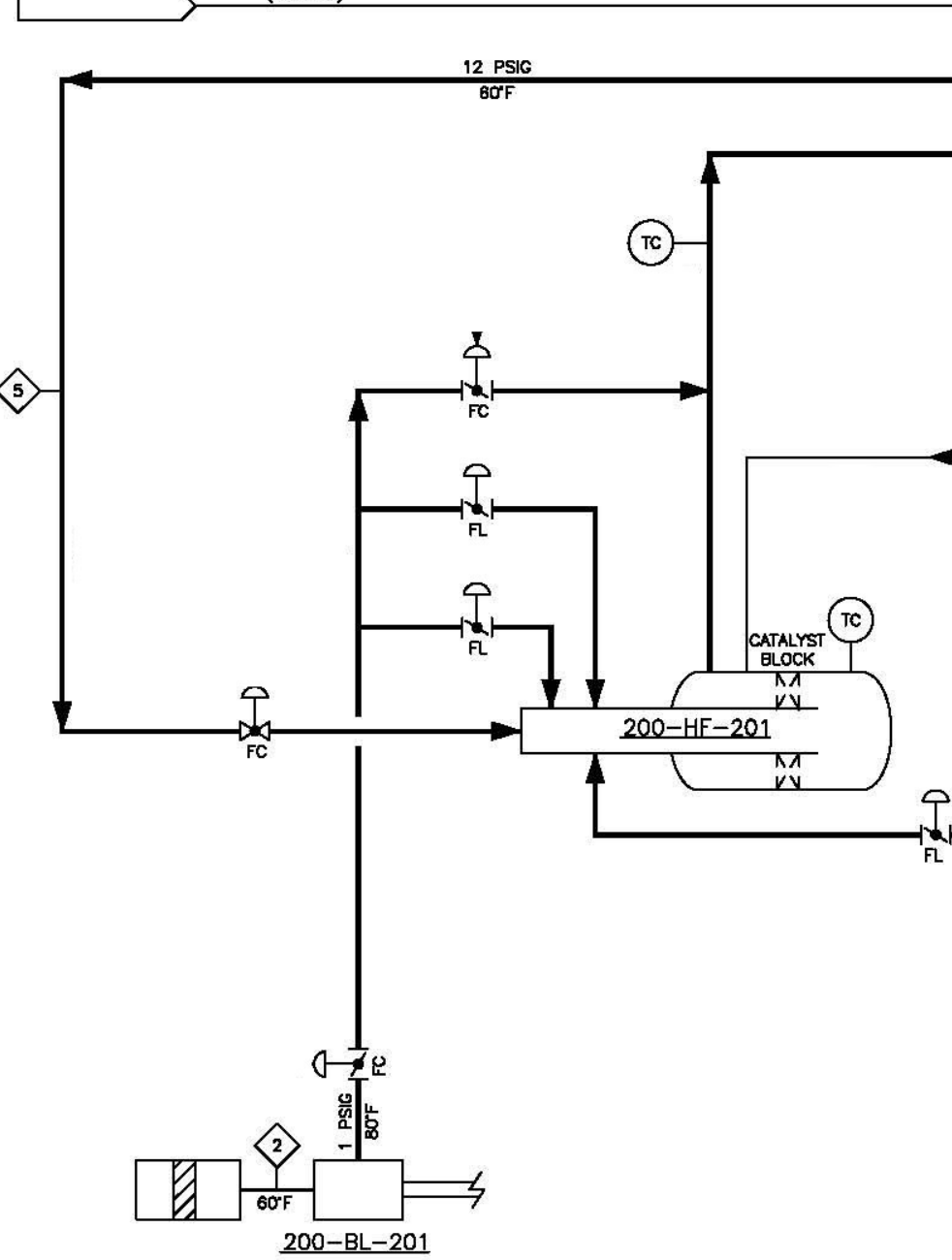

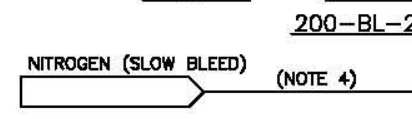

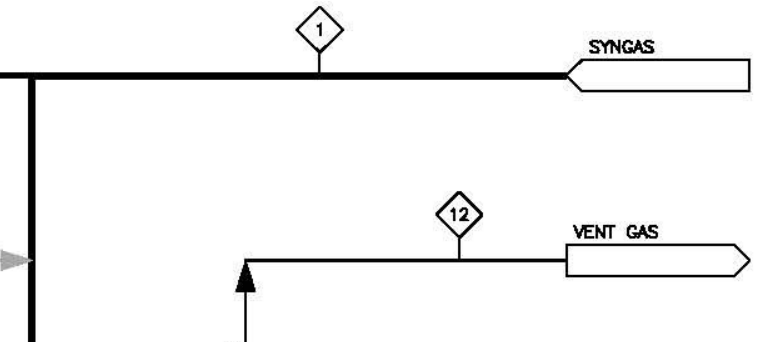

VENT GAS

I NGAS
TMENT

(T)-

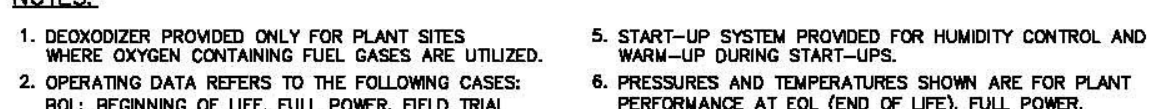

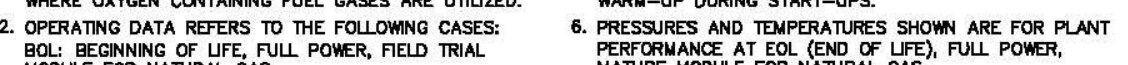

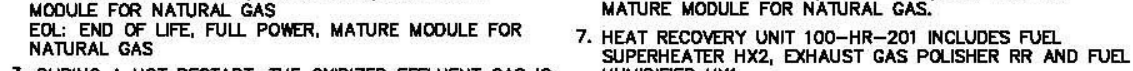

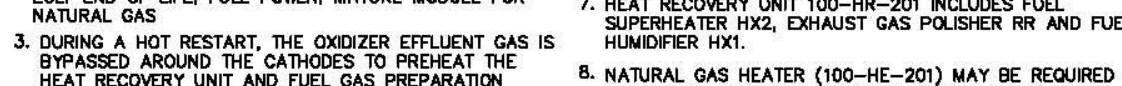

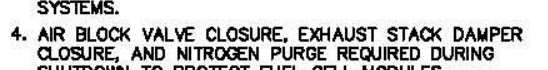

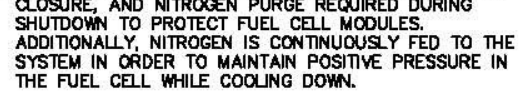




\section{Appendix B-1}

\section{Calculated Stream Data for Syngas Operation}


APPENDIX B-1

Calculated Stream Data for Syngas Operation

\begin{tabular}{|c|c|c|c|c|c|c|c|c|c|c|c|c|}
\hline Stream No. & \multicolumn{2}{|c|}{1} & \multicolumn{2}{|c|}{2} & \multicolumn{2}{|c|}{3} & \multicolumn{2}{|c|}{4} & \multicolumn{2}{|c|}{6} & \multicolumn{2}{|c|}{7} \\
\hline Name & \multicolumn{2}{|c|}{ Syngas Feed } & \multicolumn{2}{|c|}{ Air in } & \multicolumn{2}{|c|}{ Water in } & \multicolumn{2}{|c|}{ Humihex in } & \multicolumn{2}{|c|}{ Humihex out } & \multicolumn{2}{|c|}{ Methanator out } \\
\hline & & & & & & & & & & & & \\
\hline Molar flow lbmol/h & \multicolumn{2}{|c|}{150.12} & \multicolumn{2}{|c|}{537.58} & \multicolumn{2}{|c|}{166.57} & \multicolumn{2}{|c|}{145.23} & \multicolumn{2}{|c|}{145.23} & \multicolumn{2}{|c|}{278.71} \\
\hline Mass flow $\mathrm{lb} / \mathrm{h}$ & \multirow{2}{*}{\multicolumn{2}{|c|}{$\frac{3,305.4}{53^{\circ}}$}} & 15,4 & 49.8 & & & 2,85 & 53.5 & 2,85 & & 6,30 & \\
\hline Temp F & & & \multicolumn{2}{|c|}{$77^{\circ}$} & \multicolumn{2}{|c|}{$212^{\circ}$} & \multicolumn{2}{|c|}{$168^{\circ}$} & \multicolumn{2}{|c|}{$466^{\circ}$} & \multicolumn{2}{|c|}{$841^{\circ}$} \\
\hline Pres psia & \multicolumn{2}{|c|}{199.70} & 14. & & 179 & & 27.8 & & 26. & & 16. & \\
\hline IWCg & 5,12 & 0.76 & 0.1 & & 4,56 & 7.18 & 362. & & 328 & & 61. & \\
\hline Enth MMBtu/h & -7.7 & & -0.5 & & -20 & 076 & -13 & 141 & -11. & 523 & -25 . & 568 \\
\hline Vapor mole fraction & 1.0 & & 1.0 & & 0.0 & 00 & 0.5 & & 1.0 & 00 & 1.0 & 00 \\
\hline & & & & & & & & & & & & \\
\hline SCFM & 949 & & 3,40 & .00 & 1,05 & 3.50 & 918. & & 918 & & 1,76 & 2.76 \\
\hline Average mol wt & 22. & & 28. & & 0. & & 21.2 & & 19. & & 22. & \\
\hline Actual dens $\mathrm{lb} / \mathrm{ft} 3$ & 0.8 & 030 & 0.0 & 730 & 0.0 & 000 & 0.08 & 880 & 0.0 & 530 & 0.0 & 270 \\
\hline Actual vol ft $3 / \mathrm{min}$ & $6 \varepsilon$ & 3.6 & 350 & 9.0 & 0 & 0 & 30 & 0.1 & 90 & 3.1 & 383 & 5.0 \\
\hline Cp Btu/lbmol-F & 7.4 & & 7.0 & & 0.0 & & 7.6 & & 8.2 & & 9.8 & \\
\hline & & & & & & & & & & & & \\
\hline Components & \begin{tabular}{|c|}
$\mathrm{lb}-$ \\
$\mathrm{mole} / \mathrm{hr}$ \\
\end{tabular} & $\begin{array}{c}\text { mole } \\
\text { fraction }\end{array}$ & \begin{tabular}{|c|}
$\mathrm{lb}-$ \\
$\mathrm{mole} / \mathrm{hr}$
\end{tabular} & \begin{tabular}{|c|} 
mole \\
fraction
\end{tabular} & \begin{tabular}{|c|}
$\mathrm{lb}-$ \\
mole/hr
\end{tabular} & \begin{tabular}{|c|} 
mole \\
fraction
\end{tabular} & \begin{tabular}{|c|}
$\mathrm{Ib}-$ \\
$\mathrm{mole} / \mathrm{hr}$ \\
\end{tabular} & \begin{tabular}{|c|} 
mole \\
fraction
\end{tabular} & \begin{tabular}{|c|}
$\mathrm{lb}-$ \\
$\mathrm{mole} / \mathrm{hr}$
\end{tabular} & \begin{tabular}{|c|} 
mole \\
fraction
\end{tabular} & \begin{tabular}{|c|}
$\mathrm{lb}-$ \\
$\mathrm{mole} / \mathrm{hr}$
\end{tabular} & $\begin{array}{c}\text { mole } \\
\text { fraction }\end{array}$ \\
\hline Hydrogen & 49.35 & .329 & 0 & 0 & 0 & 0 & 19.51 & .134 & 19.51 & .134 & 37.32 & .134 \\
\hline Methane & 2.75 & .018 & 0 & 0 & 0 & 0 & 1.09 & .007 & 1.09 & .007 & 21.75 & .078 \\
\hline Carbon Monoxide & 66.41 & .442 & 0 & 0 & 0 & 0 & 26.23 & .181 & 26.23 & .181 & 2.47 & .009 \\
\hline \begin{tabular}{|l} 
Carbon Dioxide \\
\end{tabular} & 26.09 & .174 & 0 & 0 & 0 & 0 & 10.31 & .071 & 10.31 & .071 & 71.03 & .255 \\
\hline Water & 0.12 & .001 & 5.43 & .010 & 166.57 & 1.000 & 85.95 & .592 & 85.95 & .592 & 140.73 & .505 \\
\hline \begin{tabular}{|l|} 
Nitrogen \\
\end{tabular} & 5.42 & .036 & 420.66 & .782 & 0 & 0 & 2.14 & .015 & 2.14 & .015 & 5.42 & .019 \\
\hline Oxygen & 0 & 0 & 111.49 & .207 & 0 & 0 & 0 & 0 & 0 & 0 & 0 & 0 \\
\hline Ethylene & 0 & 0 & 0 & 0 & 0 & 0 & 0 & 0 & 0 & 0 & 0 & 0 \\
\hline Ethane & 0 & 0 & 0 & 0 & 0 & 0 & 0 & 0 & 0 & 0 & 0 & 0 \\
\hline Propylene & 0 & 0 & 0 & 0 & 0 & 0 & 0 & 0 & 0 & 0 & 0 & 0 \\
\hline Propane & 0 & 0 & 0 & 0 & 0 & 0 & 0 & 0 & 0 & 0 & 0 & 0 \\
\hline Butylene & 0 & 0 & 0 & 0 & 0 & 0 & 0 & 0 & 0 & 0 & 0 & 0 \\
\hline I-Butane & 0 & 0 & 0 & 0 & 0 & 0 & 0 & 0 & 0 & 0 & 0 & 0 \\
\hline N-Butane & 0 & 0 & 0 & 0 & 0 & 0 & 0 & 0 & 0 & 0 & 0 & 0 \\
\hline I-Pentane & 0 & 0 & 0 & 0 & 0 & 0 & 0 & 0 & 0 & 0 & 0 & 0 \\
\hline N-Pentane & 0 & 0 & 0 & 0 & 0 & 0 & 0 & 0 & 0 & 0 & 0 & 0 \\
\hline Total & 150.12 & 1.000 & 537.58 & 1.000 & 166.57 & 1.000 & 145.23 & 1.000 & 145.23 & 1.000 & 278.71 & 1.000 \\
\hline
\end{tabular}

\begin{tabular}{|c|c|c|c|c|c|c|c|c|c|c|}
\hline Stream No. & \multicolumn{2}{|c|}{8} & \multicolumn{2}{|c|}{9} & \multicolumn{2}{|c|}{10} & \multicolumn{2}{|c|}{11} & \multicolumn{2}{|c|}{12} \\
\hline Name & \multicolumn{2}{|c|}{ Superheater out } & \multicolumn{2}{|c|}{ Anode out } & \multicolumn{2}{|c|}{ Air+AGO out } & \multicolumn{2}{|c|}{ Cathode out } & \multicolumn{2}{|c|}{ Vent gas } \\
\hline Molar flow $\mathrm{lbmol} / \mathrm{h}$ & \multicolumn{2}{|c|}{278.71} & \multicolumn{2}{|c|}{407.31} & \multicolumn{2}{|c|}{927.48} & \multicolumn{2}{|c|}{792.53} & \multicolumn{2}{|c|}{796.44} \\
\hline Mass flow $\mathrm{lb} / \mathrm{h}$ & \multirow{2}{*}{\multicolumn{2}{|c|}{$\frac{6,306.4}{1013^{\circ}}$}} & \multirow{2}{*}{\multicolumn{2}{|c|}{$\frac{11,610.6}{1149^{\circ}}$}} & \multirow{2}{*}{\multicolumn{2}{|c|}{$27,060.5$}} & \multicolumn{2}{|c|}{$21,661.8$} & \multicolumn{2}{|c|}{$21,757.0$} \\
\hline Temp F & & & & & \multirow{2}{*}{\multicolumn{2}{|c|}{$\frac{1067^{\circ}}{15.86}$}} & \multirow{2}{*}{\multicolumn{2}{|c|}{$\frac{1150^{\circ}}{1580}$}} & \multicolumn{2}{|c|}{$712^{\circ}$} \\
\hline Pres psia & \multicolumn{2}{|c|}{16.39} & \multicolumn{2}{|c|}{$\begin{array}{l}1149 \\
15.94\end{array}$} & & & & & 14. & \\
\hline IWCg & \multirow{2}{*}{\multicolumn{2}{|c|}{$\begin{array}{c}46.89 \\
-25.090\end{array}$}} & \multicolumn{2}{|c|}{34.43} & 32. & & 30. & & 0.1 & \\
\hline Enth MMBtu/h & & & -45 & 821 & -46 & 742 & -32 & 253 & -35 & 769 \\
\hline Vapor mole fraction & 1.0 & & 1.0 & & 1.0 & 00 & 1.0 & & 1.0 & 00 \\
\hline & & & & & & & & & & \\
\hline SCFM & 1,762 & 2.76 & $2,57 €$ & .12 & 5,865 & 5.95 & 5,012 & 2.46 & 5,037 & 7.18 \\
\hline Average $\mathrm{mol}$ wt & 22. & & 28. & & 29. & & 27. & & 27. & \\
\hline Actual dens $\mathrm{lb} / \mathrm{ft} 3$ & 0.0 & 230 & 0.0 & 260 & 0.0 & 280 & 0.0 & 250 & 0.0 & 320 \\
\hline Actual vol ft3/min & 447 & 77.4 & 735 & 1.5 & 159 & 65.5 & 144 & 43.1 & 113 & 50.0 \\
\hline Cp Btu/lbmol-F & 10. & & 10. & & 8.9 & & 8.7 & & 8.2 & \\
\hline & & & & & & & & & & \\
\hline Components & \begin{tabular}{|c|}
$\mathrm{lb}-$ \\
$\mathrm{mole} / \mathrm{hr}$
\end{tabular} & $\begin{array}{c}\text { mole } \\
\text { fraction }\end{array}$ & \begin{tabular}{|c|}
$\mathrm{Ib}-$ \\
$\mathrm{mole} / \mathrm{hr}$
\end{tabular} & $\begin{array}{c}\text { mole } \\
\text { fraction }\end{array}$ & \begin{tabular}{|c|}
$\mathrm{lb}-$ \\
$\mathrm{mole} / \mathrm{hr}$
\end{tabular} & $\begin{array}{c}\text { mole } \\
\text { fraction }\end{array}$ & \begin{tabular}{|c|}
$\mathrm{lb}-$ \\
$\mathrm{mole} / \mathrm{hr}$
\end{tabular} & $\begin{array}{c}\text { mole } \\
\text { fraction }\end{array}$ & \begin{tabular}{|c|}
$\mathrm{lb}-$ \\
$\mathrm{mole} / \mathrm{hr}$
\end{tabular} & $\begin{array}{c}\text { mole } \\
\text { fraction }\end{array}$ \\
\hline Hydrogen & 37.32 & .134 & 24.03 & .059 & 0 & 0 & 0 & 0 & 0 & 0 \\
\hline Methane & 21.75 & .078 & 0.03 & .000 & 0 & 0 & 0 & 0 & 0.04 & .000 \\
\hline Carbon Monoxide & 2.47 & .009 & 10.81 & .027 & 0 & 0 & 0 & 0 & 0 & 0 \\
\hline Carbon Dioxide & 71.03 & 255 & 172.96 & .425 & 183.80 & .198 & 93.84 & .118 & 95.27 & .120 \\
\hline Water & 140.73 & .505 & 194.15 & .477 & 223.67 & .241 & 223.67 & .282 & 226.97 & .285 \\
\hline Nitrogen & 5.42 & .019 & 5.33 & .013 & 425.99 & .459 & 425.99 & .538 & 426.07 & .535 \\
\hline Oxygen & 0 & 0 & 0 & 0 & 94.01 & .101 & 49.02 & .062 & 48.09 & .060 \\
\hline Ethylene & 0 & 0 & 0 & 0 & 0 & 0 & 0 & 0 & 0 & 0 \\
\hline Ethane & 0 & 0 & 0 & 0 & 0 & 0 & 0 & 0 & 0 & 0 \\
\hline Propylene & 0 & 0 & 0 & 0 & 0 & 0 & 0 & 0 & 0 & 0 \\
\hline Propane & 0 & 0 & 0 & 0 & 0 & 0 & 0 & 0 & 0 & 0 \\
\hline Butylene & 0 & 0 & 0 & 0 & 0 & 0 & 0 & 0 & 0 & 0 \\
\hline I-Butane & 0 & 0 & 0 & 0 & 0 & 0 & 0 & 0 & 0 & 0 \\
\hline N-Butane & 0 & 0 & 0 & 0 & 0 & 0 & 0 & 0 & 0 & 0 \\
\hline I-Pentane & 0 & 0 & 0 & 0 & 0 & 0 & 0 & 0 & 0 & 0 \\
\hline N-Pentane & 0 & 0 & 0 & 0 & 0 & 0 & 0 & 0 & 0 & 0 \\
\hline Total & 278.71 & 1.000 & 407.31 & 1.000 & 927.47 & 1.000 & 792.53 & 1.000 & 796.44 & 1.000 \\
\hline
\end{tabular}




\section{Appendix B-2}

\section{Calculated Stream Data for Natural Gas Operation}


APPENDIX B-2

Calculated Stream Data Natural Gas Oneration

\begin{tabular}{|c|c|c|c|c|c|c|c|c|c|c|c|c|}
\hline Stream No. & \multicolumn{2}{|c|}{1} & \multicolumn{2}{|c|}{2} & \multicolumn{2}{|c|}{3} & \multicolumn{2}{|c|}{4} & \multicolumn{2}{|c|}{6} & \multicolumn{2}{|c|}{7} \\
\hline Name & \multicolumn{2}{|c|}{ NG Feed } & \multicolumn{2}{|c|}{ Air Feed } & \multicolumn{2}{|c|}{ Water in } & \multicolumn{2}{|c|}{ Humihex in } & \multicolumn{2}{|c|}{ Humihex out } & \multicolumn{2}{|c|}{ Preconverter Out } \\
\hline Molar flow lbmol/h & \multicolumn{2}{|c|}{43.20} & \multicolumn{2}{|c|}{819.81} & \multicolumn{2}{|c|}{90.00} & \multicolumn{2}{|c|}{133.21} & \multicolumn{2}{|c|}{133.21} & \multicolumn{2}{|c|}{139.27} \\
\hline Mass flow $\mathrm{lb} / \mathrm{h}$ & \multirow{2}{*}{\multicolumn{2}{|c|}{$\begin{array}{l}730.3 \\
59^{\circ}\end{array}$}} & \multirow{2}{*}{\multicolumn{2}{|c|}{$\begin{array}{c}23,560.9 \\
77^{\circ}\end{array}$}} & \multirow{2}{*}{\multicolumn{2}{|c|}{$\frac{1,621.4}{212^{\circ}}$}} & \multicolumn{2}{|c|}{$2,351.8$} & \multicolumn{2}{|c|}{$2,351.8$} & \multicolumn{2}{|c|}{$2,351.8$} \\
\hline Temp F & & & & & & & 142 & & 800 & & 619 & \\
\hline Pres psia & \multicolumn{2}{|c|}{40.00} & \multicolumn{2}{|c|}{14.70} & 179. & & 29.3 & & 26. & & 17.4 & \\
\hline IWCg & 700.3 & & 0.1 & & 4,567 & .18 & 404. & & 334. & & 77.3 & \\
\hline Enth MMBtu/h & -1.4 & & -0.8 & & -10.8 & & -12.2 & & -9.8 & & -9.9 & \\
\hline Vapor mole fraction & 1.00 & & 1.0 & & 0.00 & & 0.3 & & 1.0 & & 1.00 & \\
\hline SCFM & 273 & & 51 & & & & 842 & & & & & \\
\hline SCFM & 273.2 & & 5,185 & & 569. & & 842. & & 842. & & $880.8-2-x-x$ & \\
\hline Average mol wt & 16.9 & & 28.7 & & 0.0 & & 17.0 & & 17. & & 16.8 & \\
\hline Actual dens $\mathrm{lb} / \mathrm{ft} 3$ & 0.12 & & 0.07 & & 0.00 & & 0.07 & & 0.03 & & 0.02 & 260 \\
\hline Actual vol ft3/min & 99. & & 535 & & 0. & & 176 & & 111 & & 153 & \\
\hline Cp Btu/lbmol-F & 8.7 & & 7.0 & & 0.0 & & 9.1 & & 10. & & 9.7 & \\
\hline Components & lb-mole/hr & $\begin{array}{c}\text { mole } \\
\text { fraction }\end{array}$ & lb-mole/hr & $\begin{array}{c}\text { mole } \\
\text { fraction }\end{array}$ & |lb-mole/hr & $\begin{array}{c}\text { mole } \\
\text { fraction }\end{array}$ & Ib-mole/hr & $\begin{array}{c}\text { mole } \\
\text { fraction }\end{array}$ & Ib-mole/hr & $\begin{array}{c}\text { mole } \\
\text { fraction }\end{array}$ & Ib-mole/hr & $\begin{array}{c}\text { mole } \\
\text { fraction }\end{array}$ \\
\hline Hydrogen & 0.00 & .000 & 0 & 0 & 0 & 0 & 0.02 & .000 & 0.02 & .000 & 10.71 & .077 \\
\hline Methane & 40.99 & .949 & 0 & 0 & 0 & 0 & 40.99 & .308 & 40.99 & .308 & 40.65 & .292 \\
\hline Carbon Monoxide & 0 & 0 & 0 & 0 & 0 & 0 & 0 & 0 & 0 & 0 & 0.02 & .000 \\
\hline Carbon Dioxide & 0.39 & .009 & 0 & 0 & 0 & 0 & 0.40 & .003 & 0.40 & .003 & 3.41 & .024 \\
\hline Water & 0 & 0 & 8.28 & .010 & 90.00 & 1.000 & 89.99 & .676 & 89.99 & .676 & 83.94 & .603 \\
\hline Nitrogen & 0.55 & .013 & 641.50 & .783 & 0 & 0 & 0.55 & .004 & 0.55 & .004 & 0.55 & .004 \\
\hline Oxygen & 0 & 0 & 170.03 & .207 & 0 & 0 & 0 & 0 & 0 & 0 & 0 & 0 \\
\hline Ethylene & 0 & 0 & 0 & 0 & 0 & 0 & 0 & 0 & 0 & 0 & 0 & 0 \\
\hline Ethane & 1.10 & .026 & 0 & 0 & 0 & 0 & 1.10 & .008 & 1.10 & .008 & 0 & 0 \\
\hline Propylene & 0 & 0 & 0 & 0 & 0 & 0 & 0 & 0 & 0 & 0 & 0 & 0 \\
\hline Propane & 0.16 & .004 & 0 & 0 & 0 & 0 & 0.16 & .001 & 0.16 & .001 & 0 & 0 \\
\hline Butylene & 0 & 0 & 0 & 0 & 0 & 0 & 0 & 0 & 0 & 0 & 0 & 0 \\
\hline I-Butane & 0 & 0 & 0 & 0 & 0 & 0 & 0 & 0 & 0 & 0 & 0 & 0 \\
\hline N-Butane & 0 & 0 & 0 & 0 & 0 & 0 & 0 & 0 & 0 & 0 & 0 & 0 \\
\hline I-Pentane & 0 & 0 & 0 & 0 & 0 & 0 & 0 & 0 & 0 & 0 & 0 & 0 \\
\hline N-Pentane & 0 & 0 & 0 & 0 & 0 & 0 & 0 & 0 & 0 & 0 & 0 & 0 \\
\hline Total & 43.20 & 1.000 & 819.81 & 1.000 & 90.00 & 1.000 & 133.21 & 1.000 & 133.21 & 1.000 & 139.27 & 1.000 \\
\hline
\end{tabular}

\begin{tabular}{|c|c|c|c|c|c|c|c|c|c|c|}
\hline Stream No. & \multicolumn{2}{|c|}{8} & \multicolumn{2}{|c|}{9} & \multicolumn{2}{|c|}{10} & \multicolumn{2}{|c|}{11} & \multicolumn{2}{|c|}{12} \\
\hline Name & \multicolumn{2}{|c|}{ Superheater out } & \multicolumn{2}{|c|}{ Anode out } & \multicolumn{2}{|c|}{ Air+AGO out } & \multicolumn{2}{|c|}{ Cathode out } & \multicolumn{2}{|c|}{ Vent Gas } \\
\hline Molar flow lbmol/h & \multicolumn{2}{|c|}{139.27} & \multicolumn{2}{|c|}{335.31} & \multicolumn{2}{|c|}{$1,129.11$} & \multicolumn{2}{|c|}{951.74} & \multicolumn{2}{|c|}{953.78} \\
\hline Mass flow $\mathrm{lb} / \mathrm{h}$ & \multirow{2}{*}{\multicolumn{2}{|c|}{$\begin{array}{l}2,351.8 \\
1012^{\circ}\end{array}$}} & \multirow{2}{*}{\multicolumn{2}{|c|}{$9,412.1$}} & \multicolumn{2}{|c|}{$32,973.8$} & \multicolumn{2}{|c|}{$25,878.2$} & \multicolumn{2}{|c|}{$25,914.2$} \\
\hline Temp F & & & & & \multicolumn{2}{|c|}{$1047^{\circ}$} & \multicolumn{2}{|c|}{$1105^{\circ}$} & \multicolumn{2}{|c|}{$691^{\circ}$} \\
\hline Pres psia & \multicolumn{2}{|c|}{$\frac{1012^{\circ}}{16.49}$} & \multicolumn{2}{|c|}{16.45} & 16. & & 16.2 & & 14. & \\
\hline IWCg & \multicolumn{2}{|c|}{49.66} & \multicolumn{2}{|c|}{48.55} & 44. & & $43 . c$ & & 0.1 & \\
\hline Enth MMBtu/h & -9.3 & & $-36.3^{3} x+y+x$ & & -37 & & -18.7 & & -22 & 217 \\
\hline Vapor mole fraction & 1.0 & & 1.0 & & 1.0 & & 1.0 & & 1.0 & \\
\hline SCFM & 880 & & 2120 & & 7141 & & 6010 & & 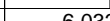 & \\
\hline Average mol wt & 16. & & 28.0 & & 29 & & 27 & & 27 & \\
\hline Actual dens $\mathrm{lb} / \mathrm{ft} 3$ & 0.0 & & 0.02 & & 0.0 & & 0.02 & & 0.0 & 320 \\
\hline Actual vol ft3/min & 222 & & 570 & & 186 & 15.8 & 1635 & 3.9 & 133 & 58.9 \\
\hline Cp Btu/lbmol-F & 10. & & 10.2 & & 8.5 & & 8.2 & & 7.7 & \\
\hline & & & & & & & & & & \\
\hline Components & Ib-mole/hr & $\begin{array}{c}\text { mole } \\
\text { fraction }\end{array}$ & lb-mole/hr & $\begin{array}{c}\text { mole } \\
\text { fraction }\end{array}$ & Ib-mole/hr & $\begin{array}{c}\text { mole } \\
\text { fraction }\end{array}$ & lb-mole/hr & $\begin{array}{c}\text { mole } \\
\text { fraction }\end{array}$ & Ib-mole/hr & $\begin{array}{c}\text { mole } \\
\text { fraction }\end{array}$ \\
\hline Hydrogen & 10.71 & .077 & 35.59 & .106 & 0 & 0 & 0 & 0 & 0 & 0 \\
\hline Methane & 40.65 & .292 & 0.10 & .000 & 0 & 0 & 0 & 0 & 0.15 & .000 \\
\hline Carbon Monoxide & 0.02 & .000 & 16.49 & .049 & 0 & 0 & 0 & 0 & 0 & 0 \\
\hline Carbon Dioxide & 3.41 & .024 & 145.06 & .433 & 161.71 & .143 & 43.47 & .046 & 44.03 & .046 \\
\hline Water & 83.94 & .603 & 137.52 & .410 & 181.65 & .161 & 181.65 & .191 & 184.05 & .193 \\
\hline Nitrogen & 0.55 & .004 & 0.54 & .002 & 642.04 & .569 & 642.04 & .675 & 642.05 & .673 \\
\hline Oxygen & 0 & 0 & 0 & 0 & 143.71 & .127 & 84.59 & .089 & 83.50 & .088 \\
\hline Ethylene & 0 & 0 & 0 & 0 & 0 & 0 & 0 & 0 & 0 & 0 \\
\hline Ethane & 0 & 0 & 0 & 0 & 0 & 0 & 0 & 0 & 0 & 0 \\
\hline Propylene & 0 & 0 & 0 & 0 & 0 & 0 & 0 & 0 & 0 & 0 \\
\hline Propane & 0 & 0 & 0 & 0 & 0 & 0 & 0 & 0 & 0 & 0 \\
\hline Butylene & 0 & 0 & 0 & 0 & 0 & 0 & 0 & 0 & 0 & 0 \\
\hline I-Butane & 0 & 0 & 0 & 0 & 0 & 0 & 0 & 0 & 0 & 0 \\
\hline N-Butane & 0 & 0 & 0 & 0 & 0 & 0 & 0 & 0 & 0 & 0 \\
\hline I-Pentane & 0 & 0 & 0 & 0 & 0 & 0 & 0 & 0 & 0 & 0 \\
\hline N-Pentane & 0 & 0 & 0 & 0 & 0 & 0 & 0 & 0 & 0 & 0 \\
\hline Total & 139.27 & 1.000 & 335.31 & 1.000 & $1,129.10$ & 1.000 & 951.74 & 1.000 & 953.78 & 1.000 \\
\hline
\end{tabular}




\section{Appendix C}

Syngas Treatment System

\section{Process Flow Diagram and Equipment Layout}




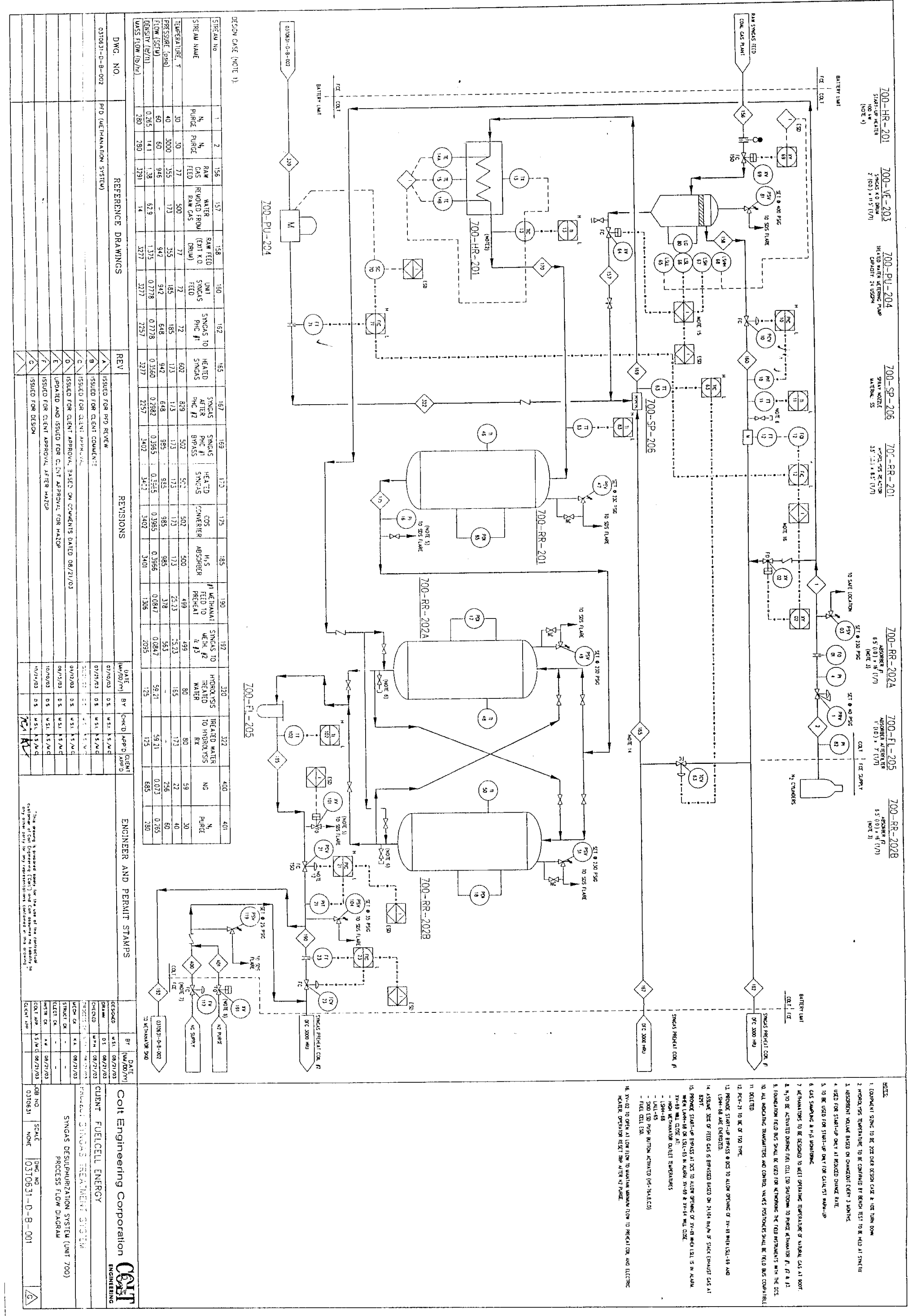




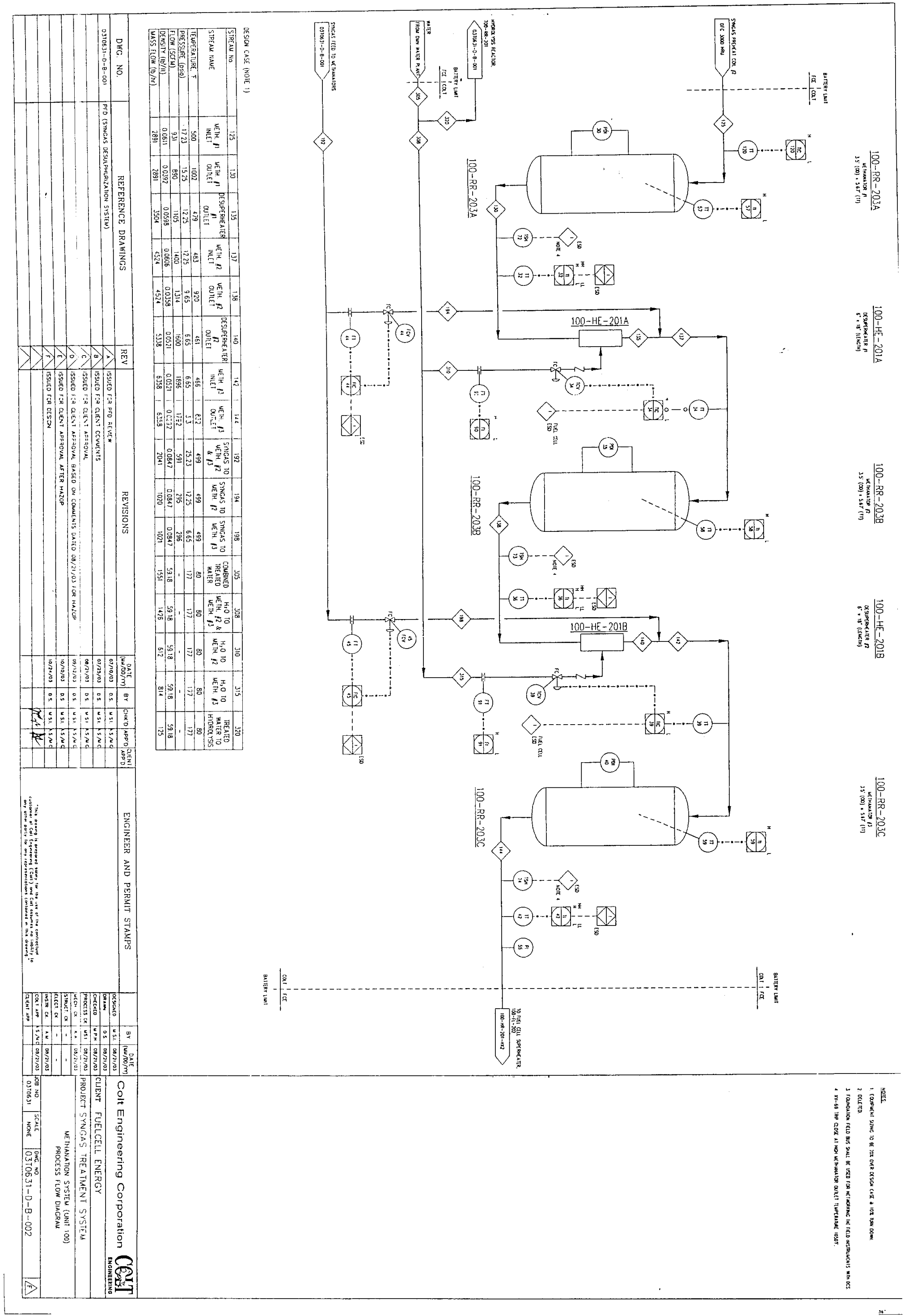




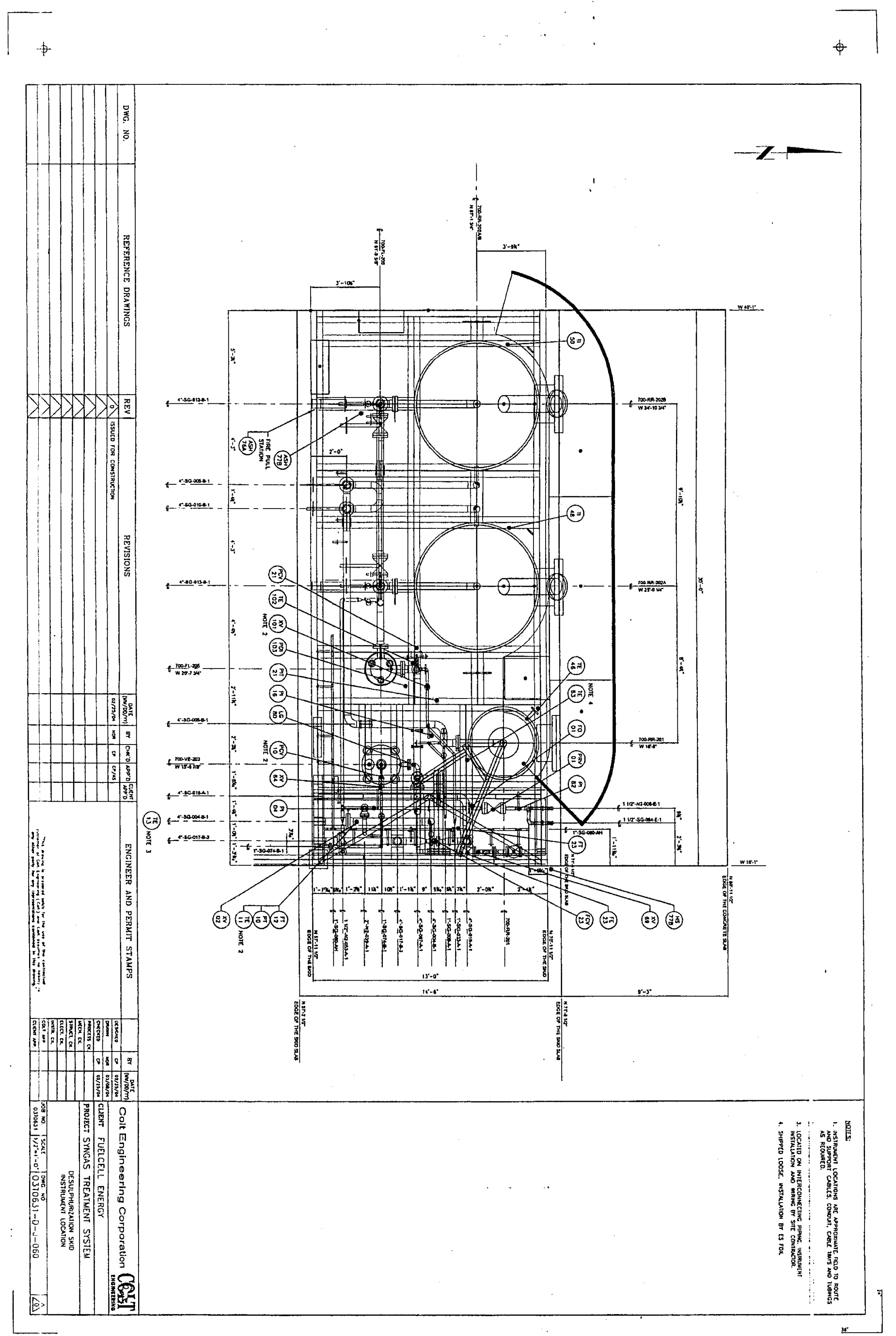




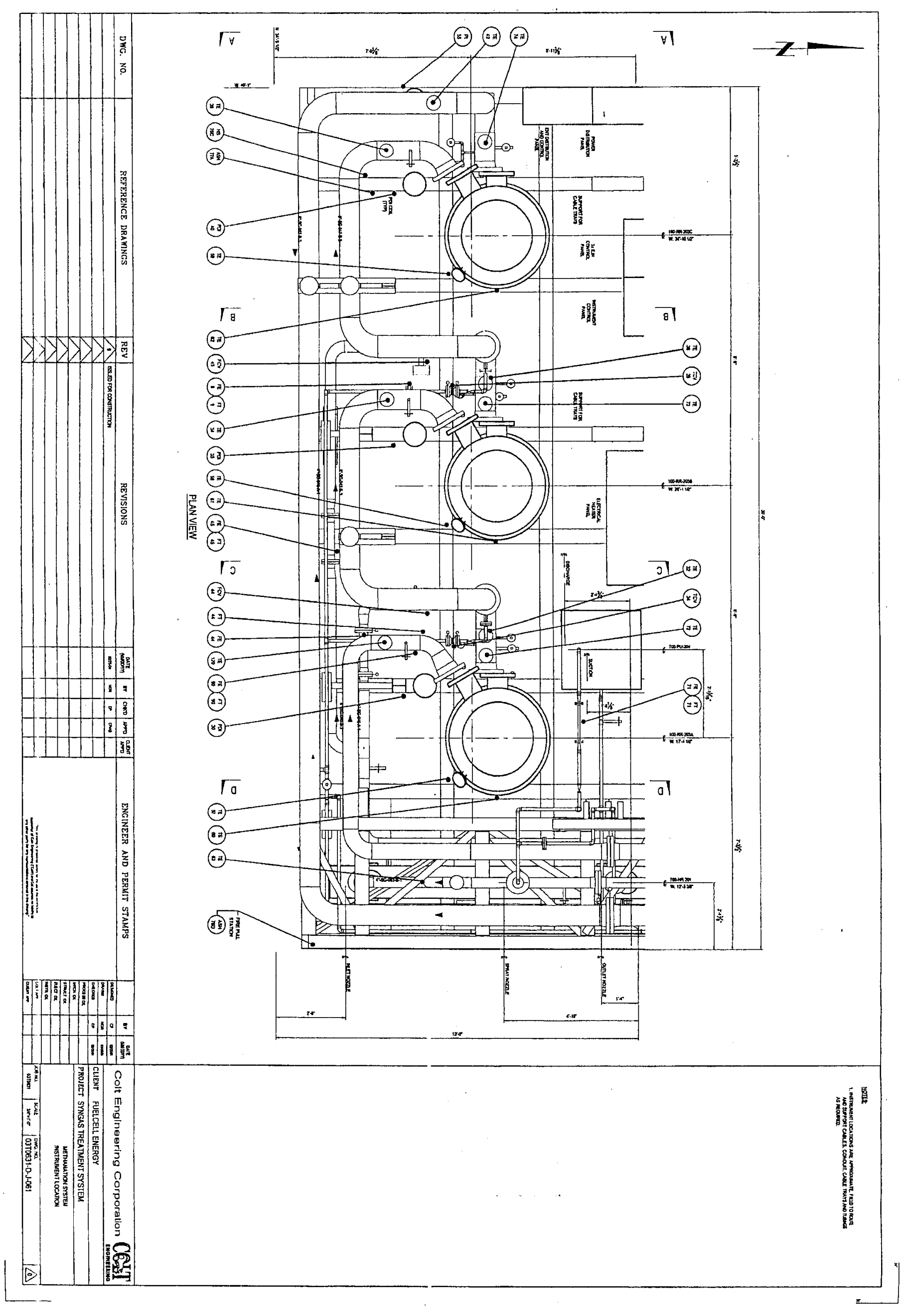




\section{Appendix D}

\section{Plot Plan for Entire Fuel Cell Power Plant}


